\title{
Selected Issues of Safe Operation of the Railway Traffic Control System in the Event of Exposition to Damage Caused by Lightning Discharges
}

\author{
Renata Markowska $^{1}$ (D) and Zofia Wróbel ${ }^{2, *(D)}$ \\ 1 Faculty of Electrical Engineering, Bialystok University of Technology, Wiejska 45d, 15-351 Białystok, Poland; \\ r.markowska@pb.edu.pl \\ 2 PKP Polish Railway Lines JSC, Railway Lines Establishment in Rzeszów, St. Batorego 26 Str., \\ 35-005 Rzeszów, Poland \\ * Correspondence: zwrobel@prz.edu.pl
}

check for updates

Citation: Markowska, R.; Wróbel, Z. Selected Issues of Safe Operation of the Railway Traffic Control System in the Event of Exposition to Damage Caused by Lightning Discharges. Energies 2021, 14, 5808. https:// doi.org/10.3390/en14185808

Academic Editor: Gilbert Ahamer

Received: 30 July 2021

Accepted: 9 September 2021

Published: 14 September 2021

Publisher's Note: MDPI stays neutral with regard to jurisdictional claims in published maps and institutional affiliations.

Copyright: (c) 2021 by the authors. Licensee MDPI, Basel, Switzerland. This article is an open access article distributed under the terms and conditions of the Creative Commons Attribution (CC BY) license (https:// creativecommons.org/licenses/by/ $4.0 /$ )

\begin{abstract}
Lightning discharge becomes a serious source of interference and damage for electronic and electrical power systems. Safe and reliable operation of railway traffic control systems requires proper protection against the effects of lightning. However, the current standards on lightning protection, PN-EN/EN/IEC 62305, do not cover railway objects. Moreover, there are no other standards or recommendations dedicated to the railway. The paper is an attempt to apply the procedure of lightning risk management according to PN-EN 62305-2 to select the proper protection measures in railway objects. A case study for the signal box with installed relaying and digital stations of the railway traffic control system is analyzed. The analysis comprises calculations based on the current standard PN-EN 62305-2:2012 but including the issues specific to railway traffic control. The risks of lightning losses have been calculated for two cases: without lightning protection measures and with protection measures proposed to decrease the risks below the tolerable values. The results show that a practically effective solution to reduce the risks is applying surge protective devices with proper characteristics. Another way is replacing unshielded incoming lines with shielded ones of given shield bonding way, and supplementing it with surge protective devices when necessary.
\end{abstract}

Keywords: lightning protection; lightning impact on railway traffic control devices; lightning protection level; lightning risk management; risk of lightning loss in railway systems

\section{Introduction}

Observations from satellite recordings show that there are on average about 2000 thunderstorms on earth at any given moment [1-5]. As a result of their impact, various damages to both private and public facilities are observed. Railway installations are also significantly exposed to such influences. In the case of serious damage to equipment, PKP commissioning analyzes the strokes recorded by lightning location systems. For example, the recorded strokes were analyzed using the LINET system [1]. The system showed a lot of strokes at a distance of $2 \mathrm{~km}$ from the affected railway line [1,6-9]. The place of the discharge is located by the system with an error of 150-200 m. The location method is based on the use of the TOA (Time-of-Arrival) technique optimized through the use of GPS. The mean time resolution error for the system is $0.2 \mu \mathrm{s}[9,10]$. On the analyzed section of the line, at a distance of $20 \mathrm{~m}$ from the track axis and $40 \mathrm{~m}$ from the non-traction line (NTL), lightning currents with the highest value of $157.5 \mathrm{kA}$ were recorded [1].

These data should be taken into account in particular by designers through a thorough analysis of storm maps when designing railway traffic control systems and choosing its devices. Moreover, knowledge about lightning occurrence is a key point in adopting adequate protection measures against direct and indirect effects of lightning discharges [10-14]. However, the random occurrence and a large number of factors influencing the hazard, 
its consequential damage, and related loss make the decision about the necessity and the method of lightning and surge protection complicated [15-17]. Therefore the decision should be preceded with an estimation of the risk of losses, which facilitates the evaluation of the resulting hazards caused by lightning and the related damage.

Lightning discharge is one of the most important factors that influence the safety of railway traffic control (RTC) systems [18]. This is related to a high exposition of the RTC system to atmospheric discharges (wire communication over long distances) and low immunity levels of the system components. Moreover, the consequences of damage to the system may be very serious.

Safe and reliable operation of RTC systems requires adopting proper protection measures against direct and indirect effects of lightning. According to Polish standard on lightning protection PN-EN 62305 [19-23], which is identical to the corresponding European and International standards EN/IEC 62305 [19-23], and similar to ITU Recommendation K.39 [24], the choice of protection measures must be based on the analysis of the risk of lightning losses [25,26], which is described in part 2 of the standards 62305-2 [20,21]. This permits the correct and economic selection of lightning protection systems and other protection measures, for the given object type, its equipment, and the way of using them [16]. The standards are applicable for many types of building structures. They can be easily adapted for analysis of typical private and public buildings, e.g., residential, schools, museums, telecommunication centers, commercial and industrial facilities $[15,16,18]$. However, the standards do not cover railway objects [19-23]. These objects have their own specific features which are not addressed in the standards 62305-2 [20,21] or whose application in the standard procedure is not straightforward. Moreover, there is no dedicated standard or other recommendations that could be used for railway objects in this respect. It is, therefore, necessary to develop special recommendations for internal use within the railway.

The paper is an attempt to apply the procedure of lightning risk management, according to PN-EN 62305-2:2012 [21], to select the proper protection measures in railway objects. The analysis of the risk of losses due to atmospheric discharges in the railway traffic control system has been presented. A case study for the chosen object type-signal box with installed relaying and digital station of the railway traffic control system and a fragment of a track section-has been analyzed. In the analysis, a track foreman fragment with three-level crossings, a feeding line, an antenna mast, two telephone lines, three-level crossings, and two farthest advanced signals are taken into account. The analysis has been done with calculation performed according to PN-EN 62305-2:2012 [21]. As part of the lightning risk management procedure, the risks of lightning losses without and with protection measures have been calculated. This has shown a general necessity of application of specific overvoltage protection measures for the considered type of railway objects.

\section{Materials and Methods}

2.1. Lightning Risk Management According to PN-EN 62305-2:2012

According to the standard PN-EN 62305-2:2012 pt. 3.1.31 [21] the lightning risk $\mathrm{R}$ is defined as the probable average value of one year's loss (people and goods) as a consequence of lightning, related to the entire value (people and goods) of the object subjected to the protection. There are four types of risk $R\left(R_{1}, R_{2}, R_{3}, R_{4}\right)$ of corresponding losses $\mathrm{L}\left(\mathrm{L}_{1}, \mathrm{~L}_{2}, \mathrm{~L}_{3}, \mathrm{~L}_{4}\right)$, dependent on the object type:

- $\mathrm{R}_{1}$ : Risk of loss of life or permanent injury $\mathrm{L}_{1}$;

- $\mathrm{R}_{2}$ : Risk of loss of service to the public $\mathrm{L}_{2}$;

- $\mathrm{R}_{3}$ : Risk of loss of cultural heritage $\mathrm{L}_{3}$;

- $\mathrm{R}_{4}$ : Risk of loss of economic value $\mathrm{L}_{4}$.

Each type of risk $\mathrm{R}$ is the sum of its components $\mathrm{R}_{X}$ related to the source $\mathrm{S}$ and the type $\mathrm{D}$ of damage causing the loss (Table 1 ). The risk components $\mathrm{R}_{\mathrm{X}}$ are calculated based on the overall formula:

$$
\mathrm{R}_{\mathrm{X}}=\mathrm{N}_{\mathrm{X}} \times \mathrm{P}_{\mathrm{X}} \times \mathrm{L}_{\mathrm{X}}
$$


where:

$\mathrm{N}_{X}$ - Number of dangerous events related to particular source and type of damage (Table 1);

$\mathrm{P}_{\mathrm{X}}$-Probability of damage caused by one dangerous event of a particular source of damage;

$\mathrm{L}_{\mathrm{X}}$ - Loss factor that allows estimating the loss related to the damage.

Table 1. Components $R_{X}$ of the risk $R$, related to the source $S$ and type $D$ of damage $[20,21]$.

\begin{tabular}{|c|c|c|c|c|c|}
\hline \multirow[b]{2}{*}{ Type of Damage } & \multicolumn{4}{|c|}{ Lightning Flash: } & \multirow[b]{2}{*}{$\begin{array}{c}\text { Risk Related to } \\
\text { the Type of } \\
\text { Damage D }\end{array}$} \\
\hline & $\begin{array}{c}\text { To the } \\
\text { Structure (S1) }\end{array}$ & $\begin{array}{l}\text { Near the } \\
\text { Structure (S2) }\end{array}$ & $\begin{array}{l}\text { To a Connected } \\
\text { Line (S3) }\end{array}$ & $\begin{array}{c}\text { Near a } \\
\text { Connected } \\
\text { Line (S4) }\end{array}$ & \\
\hline $\begin{array}{l}\text { Injuries due to Electric Shock } \\
\text { (D1) }\end{array}$ & $\begin{aligned} \mathrm{R}_{\mathrm{A}}= & \mathrm{N}_{\mathrm{D}} \times \mathrm{P}_{\mathrm{A}} \\
& \times \mathrm{L}_{\mathrm{A}}\end{aligned}$ & $\mathrm{NA}^{1}$ & $\begin{array}{c}\mathrm{R}_{\mathrm{U}}=\left(\mathrm{N}_{\mathrm{L}}+\right. \\
\left.\mathrm{N}_{\mathrm{DJ}}\right) \times \mathrm{P}_{\mathrm{U}} \times \\
\mathrm{L}_{\mathrm{U}}\end{array}$ & $\mathrm{NA}^{1}$ & $\mathrm{R}_{\mathrm{A}}+\mathrm{R}_{\mathrm{U}}$ \\
\hline Physical Damage (D2) & $\begin{aligned} \mathrm{R}_{\mathrm{B}}= & \mathrm{N}_{\mathrm{D}} \times \mathrm{P}_{\mathrm{B}} \\
& \times \mathrm{L}_{\mathrm{B}}\end{aligned}$ & $\mathrm{NA}^{1}$ & $\begin{array}{c}\mathrm{R}_{\mathrm{V}}=\left(\mathrm{N}_{\mathrm{L}}+\mathrm{N}_{\mathrm{DJ}}\right) \\
\times \mathrm{P}_{\mathrm{V}} \times \mathrm{L}_{\mathrm{V}}\end{array}$ & $\mathrm{NA}^{1}$ & $R_{B}+R_{V}$ \\
\hline Failure of Internal Systems (D3) & $\begin{aligned} \mathrm{R}_{\mathrm{C}}= & \mathrm{N}_{\mathrm{D}} \times \mathrm{P}_{\mathrm{C}} \\
& \times \mathrm{L}_{\mathrm{C}}\end{aligned}$ & $\begin{aligned} \mathrm{R}_{\mathrm{M}}= & \mathrm{N}_{\mathrm{M}} \times \mathrm{P}_{\mathrm{M}} \\
& \times \mathrm{L}_{\mathrm{M}}\end{aligned}$ & $\begin{array}{c}\mathrm{R}_{\mathrm{W}}=\left(\mathrm{N}_{\mathrm{L}}+\right. \\
\left.\mathrm{N}_{\mathrm{DJ}}\right) \times \mathrm{P}_{\mathrm{W}} \times \\
\mathrm{L}_{\mathrm{W}}\end{array}$ & $\mathrm{R}_{\mathrm{Z}}=\underset{\mathrm{L}_{\mathrm{Z}}}{\mathrm{N}_{\mathrm{I}} \times \mathrm{P}_{\mathrm{Z}} \times}$ & $\begin{array}{c}R_{C}+R_{M}+R_{W} \\
+R_{Z}\end{array}$ \\
\hline $\begin{array}{c}\text { Risk Related to the Source of } \\
\text { Damage S }\end{array}$ & $\mathrm{R}_{\mathrm{A}}+\mathrm{R}_{\mathrm{B}}+\mathrm{R}_{\mathrm{C}}$ & $\mathrm{R}_{\mathrm{M}}$ & $\mathrm{R}_{\mathrm{U}}+\mathrm{R}_{\mathrm{V}}+\mathrm{R}_{\mathrm{W}}$ & $\mathrm{R}_{\mathrm{Z}}$ & $\begin{array}{c}\mathrm{R}=\mathrm{R}_{\mathrm{A}}+\mathrm{R}_{\mathrm{B}}+ \\
\mathrm{R}_{\mathrm{C}}+\mathrm{R}_{\mathrm{M}}+\mathrm{R}_{\mathrm{U}}+ \\
\mathrm{R}_{\mathrm{V}}+\mathrm{R}_{\mathrm{W}}+\mathrm{R}_{\mathrm{Z}}\end{array}$ \\
\hline
\end{tabular}

${ }^{1}$ NA—not applicable, i.e., no type of damage for a particular source of damage. $N_{D}$-number of dangerous events due to lightning flashes to the object in concern. $N_{M}$-number of dangerous events due to lightning flashes to the ground near the object. $N_{L}-$ number of dangerous events due to lightning flashes to the line incoming to the object. $\mathrm{N}_{\mathrm{DI}}$-number of dangerous events due to lightning flashes to the adjacent structure, i.e., the object at the opposite end of the line incoming to the object in concern. $\mathrm{N}_{\mathrm{I}}$-number of dangerous events due to lightning flashes to the ground near the incoming line.

In the formulas, the number of dangerous events depends on the lightning occurrence as well as the geometry, main properties, and localization of the object and external lines connected to it. The probability of damage is dependent on the characteristics of the object and incoming external lines as well as the protection measures adopted for the object and lines. The loss factor is dependent on the type and purpose of the object as well as the characteristics of the object and connected lines. The detailed rules for calculating or determining particular factors $\mathrm{N}_{\mathbf{X}}, \mathrm{P}_{\mathbf{X}}$, and $\mathrm{L}_{\mathrm{X}}$ are quite complex [21].

Qualifying the necessity of the lightning protection for the object according to the standard, the designer should take into account all the types of risks $\mathrm{R}$ that are applicable for the object, depending on its type and purpose. Then, for each type of risk identified in the object, he should follow the management risk procedure:

1. Identify the components $\mathrm{R}_{X}$ forming the risk $\mathrm{R}_{\text {; }}$

2. Calculate the components $\mathrm{R}_{X}$ and the entire risk $\mathrm{R}$;

3. Identify the value of the tolerated risk $R_{T}$, based on recommendations of applicable standards or bodies having jurisdiction;

4. Compare the calculated risk $\mathrm{R}$ with the tolerated value $\mathrm{R}_{\mathrm{T}}$.

In the case of $R \leq R_{T}$, lightning protection is not necessary. For $R>R_{T}$, it is necessary to choose protection measures that have an impact on the probabilities of damage $P_{X}$ and the loss factors $L_{X}$, to reduce the risk $R$ to or below the tolerated value $R_{T}$.

As a result of such analysis, one can decide on the use of protection measures permitting the minimization of losses in the object and the proper selection of the lightning protection level. Furthermore, if the object is divided into zones, the procedure permits the correct and economic selection of protection measures individually for particular zones $[20,21,27]$. 


\subsection{Application of PN-EN 62305-2:2012 Lightning Risk Procedure to the Case Study-The Railway Object}

The railway object chosen for the case study analysis is a signal box containing relaying and computer devices of the railway traffic control (RTC) system. The object is presented in Figure $1[1,28,29]$. The equipment inside the object is connected to the following external lines:

- electrical power feeding line $230 / 400 \mathrm{~V}$ connected to the low voltage power system;

- two telecommunication lines;

- antenna cable connected to the antenna installed on a mast at the roof;

- two feeding lines $230 / 500 \mathrm{~V}$ of automatic line block system;

- three control lines of automatic level crossings;

- two signal lines for remote signaling;

- $\quad$ signal line connected to station equipment.

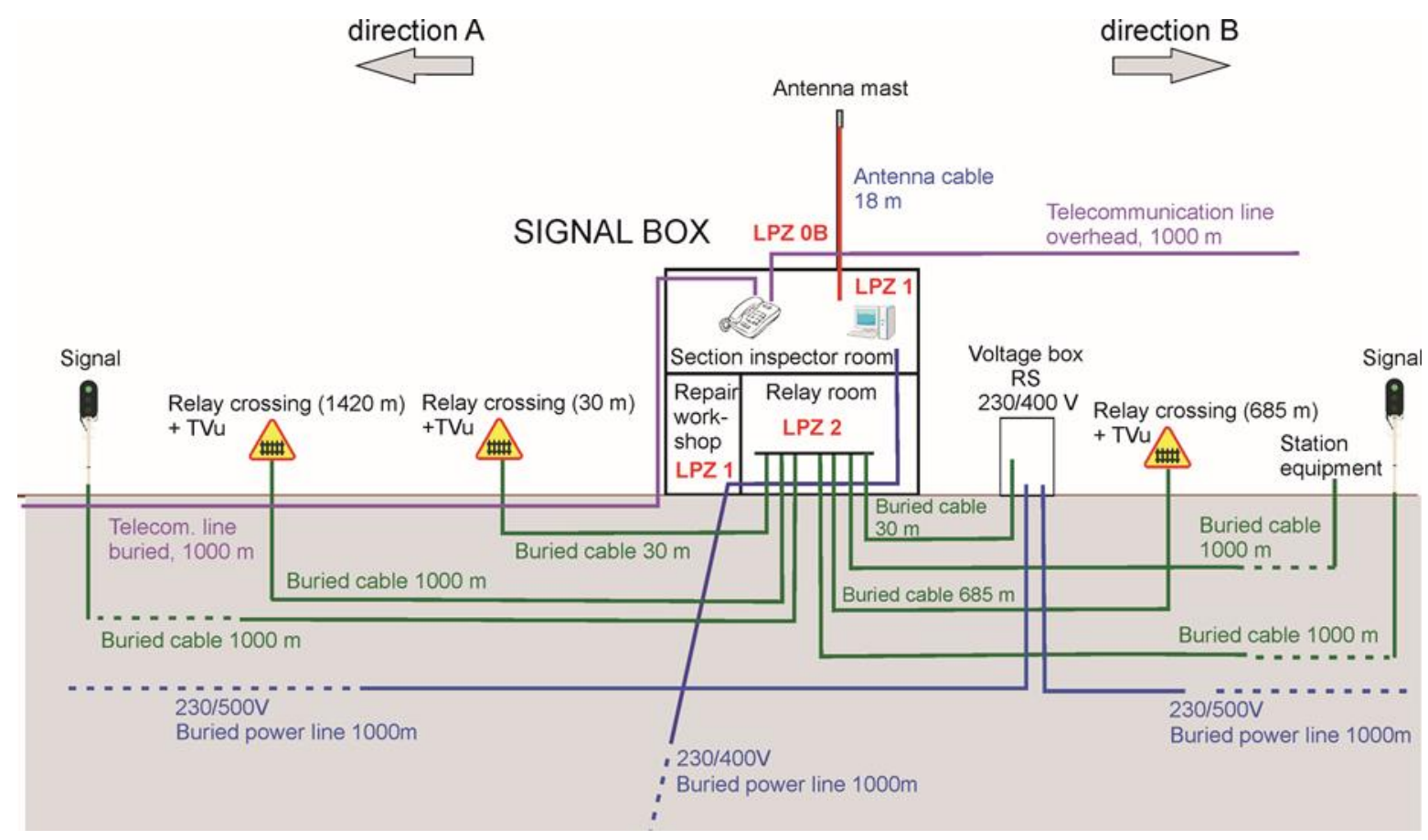

Figure 1. Analyzed railway objects with incoming external lines and devices [1,28,29].

For each line the following characteristics were determined: the type (overhead/ underground) and length of the line (outside the object), the environment (urban/suburban/rural), an adjacent structure connected to the line, the type of wiring (shielded/unshielded) and the lowest impulse withstand voltage of internal systems connected to the line.

For determining the number of dangerous events $\mathrm{N}_{X}$ in the calculation of the risk according to (1) an essential parameter is the density of lightning discharges to earth $\mathrm{Ng}$. It determines the number of lightning discharges to the ground per square kilometer per year. For areas, where the object is located, according to the density maps of lightning discharges, $\mathrm{Ng}$ is approx. 2.7 per $\mathrm{km}^{2}$ per year [21].

The number of dangerous events $\mathrm{N}_{X}$ is dependent also on the equivalent collection area of lightning flashes, which is calculated based on geometrical dimensions of the object or the incoming external line in concern. The equivalent collection area is calculated under the assumption that the object or line is located on flat ground and there are no other structures in the vicinity. Then, specific conditions of the object and incoming lines are taken into account by using defined factors dependent on the location (surrounding structures and landform), environment (rural, suburban, urban, etc.), line installation (aerial or buried), and line-type (with or without a transformer at the entry to the object) $[19,21]$. 
The characteristics of the object and incoming lines used to determine the number of dangerous events are presented in Appendix A (Tables A1-A11).

The equivalent collection areas of lightning flashes to and near the incoming lines given in Tables A2-A11 cannot be used in calculations of the numbers of dangerous events because of overlapping of the areas related to lines following the same or similar routes $[19,21]$. This is the first difficulty to come across in the considered railway object, which results from a large number of incoming external lines. To take this into account, each incoming line was classified to one of the four approximate routes A, B, C, or D, according to the direction it follows. Then, the equivalent collection area for a given route (A, B, C, D) was determined, as being the worst case among the particular collection areas of the lines following the route (the largest collection area calculated). The results are shown in Table 2.

Table 2. Worst case parameters and collection areas related to the incoming lines that follow the same routes.

\begin{tabular}{|c|c|c|c|c|c|c|}
\hline Route & $\begin{array}{c}\text { Line Length } \\
\mathrm{L}_{\mathrm{L}}(\mathrm{m})\end{array}$ & $\begin{array}{c}\text { Product of } \\
\text { Line Factors } \\
C_{I} \times C_{T} \times C_{E} \\
(-)\end{array}$ & $\begin{array}{c}\text { Equivalent } \\
\text { Collection } \\
\text { Area of Direct } \\
\text { Flashes } \\
A_{\mathrm{L}}\left(\mathbf{m}^{2}\right)\end{array}$ & $\begin{array}{c}\text { Equivalent } \\
\text { Collection } \\
\text { Area of Near } \\
\text { Flashes } \\
A_{I}\left(\mathbf{m}^{2}\right)\end{array}$ & $\begin{array}{c}\text { Product of } \\
\text { Adjacent } \\
\text { Structure } \\
\text { Factors } \\
\mathrm{C}_{\mathrm{DJ}} \times \mathrm{C}_{\mathrm{T}}(-)\end{array}$ & $\begin{array}{l}\text { Collection Area of } \\
\text { Flashes to the } \\
\text { Adjacent Structure } \\
A_{D J}\left(\mathrm{~m}^{2}\right)\end{array}$ \\
\hline$A^{1}$ & 1,420 & 0.5 & 56,400 & $4,260,000$ & 1 & 0 \\
\hline $\mathrm{B}^{2}$ & 1,030 & 0.5 & 40,800 & $3,090,000$ & 1 & 0 \\
\hline$c^{3}$ & 1,000 & 0.25 & 39,600 & $2,775,000$ & 1 & 0 \\
\hline $\mathrm{D}^{4}$ & 1,000 & 0.5 & 39,600 & $2,775,000$ & 1 & 0 \\
\hline
\end{tabular}

${ }^{1}$ Lines of route A: feeding 230/500 V direction A; control to level crossings 1 and 2; signal for remote signaling $1 .{ }^{2}$ Lines of route B: feeding 230/500 V to voltage box, direction A and direction B; Control to level crossing 3; signal to station equipment; signal for remote signaling 2.

${ }^{3}$ Lines of route C: feeding $230 / 400 \mathrm{~V}$; telephone $1 .{ }^{4}$ Lines of route D: telephone 2.

According to PN-EN 62305-2:2012 [21], for efficient and economic selection of protection measures that influence the probabilities of damage $P_{X}$ and to take into account different characteristics of particular parts of the object that influence the loss factors $\mathrm{L}_{X}$ (Table 1), the object was divided into zones. The zones created for the purpose of risk analysis according to PN-EN 62305-2:2012 [21] have been coordinated with the lightning protection zone (LPZ) concept according to PN-EN 62305 [19,21-23]. This assumption was taken for the case if, following the risk management procedure, it turned out necessary to apply protection measures.

The zoning can be made taking into account such criteria as the type of ground and floors, fire-proof barriers, spatial shielding, arrangement of internal systems, existing or proposed protection measures, type of losses, and amount of losses. Considering the lightning protection zones (LPZ), i.e. the zones for which the lightning electromagnetic environment is defined according to the LPZ concept, the following zones $Z$ have been defined for the object-signal box-(Figure 1):

- For LPZ 0A or 0B (outside the signal box):

- Z1-around the signal box, access from the ground;

- Z2-around the antenna mast, access from the roof of the signal box;

- For LPZ 1 (inside the signal box):

- Z3-section inspector auty room;

- Z4-repair workshop room;

- For LPZ 2 (inside the signal box with better shielding properties than LPZ 1 if needed):

- Z5-relay room.

The lightning protection zones LPZ are defined in standard PN-EN 62305 as follows: LPZ 0A: Zone unprotected against lightning electromagnetic pulse. 
LPZ 0B: Zone protected against direct lightning strikes by external lightning protection system (LPS). Equipment is exposed to parts of lightning currents and full lightning electromagnetic fields.

LPZ 1: Internal zone, where the failure surge currents and voltages are limited by equipotential bonding and surge protective devices (SPD), and the lightning electromagnetic field is attenuated by spatial shielding at the zone boundary.

LPZ $2 \ldots$ n: Internal zones, where current and voltage impulses are further limited by equipotential bonding and additional SPD, and the lightning electromagnetic field is further limited by additional spatial shielding at the zones' boundaries.

Determining the values of probabilities of damage $P_{X}$ (Table 1), it is necessary to know specific characteristics of the object, incoming external lines, internal electrical and electronic systems installed in the object, and applied protection measures against electric shock, lightning, and overvoltage. These characteristics can be summarized as follows:

1. External lightning protection system (LPS) on the object-no external LPS present;

2. Protection against electric shock due to direct lightning flash to the object-no protection;

3. Screening effectiveness of the structure at the boundary LPZ $0 / 1-$ no shielding;

4. Screening effectiveness of internal shields, i.e., within LPZ 1-no internal shielding;

5. Type, shielding, grounding, and isolation conditions of the incoming lines:

- antenna cable line-telecommunication (TLC), aerial, shielded with shield resistance higher than $5 \Omega / \mathrm{km}$ up to $20 \Omega / \mathrm{km}$, no connection at the entrance (internal system);

- electrical power feeding line $230 / 400 \mathrm{~V}$-power, buried, unshielded;

- electrical power feeding lines 230/500 V-power, buried unshielded;

- telecommunication line 1-TLC, buried, unshielded;

- telecommunication line 2-TLC, aerial, unshielded;

- control lines of automatic level crossings (1, 2, and 3)-TLC/data, buried, unshielded;

- $\quad$ signal line for station equipment-TLC/data, buried, unshielded;

- $\quad$ signal lines for remote signaling (1 and 2)-TLC/data, buried, unshielded;

6. Type of internal wiring of the internal electrical and electronic systems:

- antenna system-shielded;

- electrical power 230/400 V-unshielded, routing precautions to avoid large loops;

- electrical power 230/500 V-unshielded, routing precautions to avoid large loops;

- telecommunication (1 and 2) - unshielded, routing precautions to avoid large loops;

- control of level crossings (1, 2,3)-unshielded, routing precautions to avoid large loops;

- station equipment-unshielded, routing precautions to avoid large loops;

- remote signaling $(1,2)$ - unshielded, routing precautions to avoid large loops;

7. Lowest impulse withstand voltage-from $1.0 \mathrm{kV}$ to $2.5 \mathrm{kV}$, depending on the zone and the internal system;

8. Protection against electric shock due to direct lightning flash to the incoming lineselectrical insulation and/or physical restrictions, depending on the zone and the incoming line;

9. Coordinated surge protective devices (SPDs) in the internal electrical and electronic systems, according to PN-EN 62305-4 [23] —no coordinated SPDs in all systems and zones;

10. Equipotential bonding provided by SPDs at the entry of the incoming lines to the object, according to PN-EN 62305-3 [22]—no SPDs in all systems and zones.

Some of these characteristics extend to the entire object or system and some are specific only for certain zones $\mathrm{Z}$. The detailed information about these characteristics is presented in Appendix B.

The specific characteristics of the considered object and its contents, which influence the loss factors $\mathrm{L}_{\mathrm{X}}$ (Table 1), are presented in Tables 3-7. 
Table 3. Factors decreasing and increasing the number of losses in the object.

\begin{tabular}{|c|c|c|c|c|c|c|}
\hline \multirow{2}{*}{$\begin{array}{l}\text { Decreasing or } \\
\text { Increasing Factor }\end{array}$} & \multirow{2}{*}{ Symbol } & \multicolumn{5}{|c|}{ Characteristics } \\
\hline & & $\mathrm{Z1}$ & $\mathrm{Z2}$ & $\mathrm{Z3}$ & $\mathrm{Z4}$ & Z5 \\
\hline $\begin{array}{l}\text { Type of surface of } \\
\text { soil or floor }\end{array}$ & $r_{\mathrm{t}}$ & $\begin{array}{l}\text { Concrete, } \\
\text { agriculture }\end{array}$ & Asphalt & Linoleum & Linoleum & Linoleum \\
\hline $\begin{array}{l}\text { Provisions taken to } \\
\text { reduce the } \\
\text { consequences of fire }\end{array}$ & $r_{\mathrm{p}}$ & Hydrant & $\begin{array}{c}\text { Fire } \\
\text { extinguisher }\end{array}$ & $\begin{array}{c}\text { Fire } \\
\text { extinguisher }\end{array}$ & $\begin{array}{c}\text { Fire } \\
\text { extinguisher }\end{array}$ & $\begin{array}{c}\text { Fire } \\
\text { extinguisher }\end{array}$ \\
\hline $\begin{array}{l}\text { Risk of fire or } \\
\text { explosion of the } \\
\text { structure }\end{array}$ & $r_{\mathrm{f}}$ & Ordinary & Ordinary & Ordinary & Ordinary & Ordinary \\
\hline $\begin{array}{l}\text { Special hazard } \\
\text { related to panic and } \\
\text { evacuation }\end{array}$ & $h_{\mathrm{z}}$ & $\begin{array}{l}\text { No special } \\
\text { hazard }\end{array}$ & $\begin{array}{l}\text { No special } \\
\text { hazard }\end{array}$ & $\begin{array}{l}\text { Low level of } \\
\text { panic }\end{array}$ & $\begin{array}{c}\text { Low level of } \\
\text { panic }\end{array}$ & $\begin{array}{c}\text { Low level of } \\
\text { panic }\end{array}$ \\
\hline
\end{tabular}

Table 4. Characteristics influencing the typical mean values of losses depending on the type of object.

\begin{tabular}{|c|c|c|c|c|c|}
\hline \multirow[b]{2}{*}{ Type of Loss } & \multirow[b]{2}{*}{ Symbol } & $\mathrm{L}_{\mathrm{T}}$ & $\mathrm{L}_{\mathrm{F}}$ & $\mathrm{L}_{\mathrm{O}}$ & $\mathrm{L}_{\mathrm{OE}}{ }^{1}$ \\
\hline & & Injuries & Physical Damage & $\begin{array}{c}\text { Failure of Internal } \\
\text { System }\end{array}$ & $\begin{array}{c}\text { Environmental } \\
\text { Effects of Failure }\end{array}$ \\
\hline $\begin{array}{l}\text { Loss of human } \\
\text { life }\end{array}$ & $\mathrm{L}_{1}$ & All types & Other & $\begin{array}{l}\text { No danger for people } \\
\text { inside }\end{array}$ & Specific: $1.0 \times 10^{-41}$ \\
\hline $\begin{array}{l}\text { Loss of service to } \\
\text { the public }{ }^{1}\end{array}$ & $\mathrm{~L}_{2}$ & - & Specific: $1.0 \times 10^{-21}$ & Specific: $1.0 \times 10^{-31}$ & \\
\hline $\begin{array}{l}\text { Loss of cultural } \\
\text { heritage }\end{array}$ & $\mathrm{L}_{3}$ & - & No cultural heritage & - & \\
\hline Economic loss ${ }^{1}$ & $\mathrm{~L}_{4}$ & $\begin{array}{l}\text { No animals } \\
\text { present }\end{array}$ & Specific: $2.0 \times 10^{-11}$ & Specific: $2.0 \times 10^{-31}$ & \\
\hline
\end{tabular}

${ }^{1}$ Not included in the standard PN-EN/EN 62305-2 for railway objects; Proposed for the considered case.

Table 5. Presence of persons during the year in the structure, relevant to the loss of human life $\left(\mathrm{L}_{1}\right)$.

\begin{tabular}{|c|c|c|c|c|c|c|}
\hline \multirow{2}{*}{ Conditions } & \multirow{2}{*}{ Symbol } & \multicolumn{5}{|c|}{ Value } \\
\hline & & $\mathrm{Z1}$ & $\mathbf{Z 2}$ & $\mathrm{Z3}$ & $\mathrm{Z4}$ & $\mathrm{Z} 5$ \\
\hline Number of persons in the zone & $n_{\mathrm{z}}$ & 0 & 0 & 2 & 2 & 1 \\
\hline Total number of persons in the structure & $n_{\mathrm{t}}$ & & & 5 & & \\
\hline $\begin{array}{c}\text { Time in hours per year for which people are } \\
\text { present in the zone }\end{array}$ & $t_{\mathrm{z}}$ & 0 & 0 & 8760 & 2090 & 2090 \\
\hline $\begin{array}{l}\text { Time of presence of people in the dangerous } \\
\text { places outside the object }{ }^{1}\end{array}$ & $t_{e}$ & & & $2920^{1}$ & & \\
\hline
\end{tabular}

${ }^{1}$ Not included in the standard PN-EN/EN 62305-2 for railway objects; Proposed for the considered case.

Table 6. Number of users served by the object, relevant to the loss of service to the public $\left(\mathrm{L}_{2}\right)$.

\begin{tabular}{|c|c|c|c|c|c|c|}
\hline \multirow{2}{*}{ Conditions } & \multirow{2}{*}{ Symbol } & \multicolumn{5}{|c|}{ Value } \\
\hline & & $\mathrm{Z1}$ & $\mathrm{Z2}$ & Z3 & $\mathrm{Z4}$ & $\mathrm{Z} 5$ \\
\hline $\begin{array}{l}\text { Number of users served by the zone } \\
\text { (average per day) }{ }^{1}\end{array}$ & $n_{\mathrm{z}}$ & $0^{1}$ & $0^{1}$ & $5000^{1}$ & $0^{1}$ & $20,000^{1}$ \\
\hline $\begin{array}{c}\text { Total number of users served by the object } \\
\text { (average per day) }{ }^{1}\end{array}$ & $n_{\mathrm{t}}$ & & & $25,000^{1}$ & & \\
\hline
\end{tabular}

\footnotetext{
${ }^{1}$ Not included in the standard PN-EN/EN 62305-2 for railway objects; Proposed for the considered case.
} 
Table 7. Economic value of the object and its contents, relevant to the economic loss $\left(\mathrm{L}_{4}\right)$.

\begin{tabular}{|c|c|c|c|c|c|c|}
\hline \multirow{2}{*}{ Conditions } & \multirow{2}{*}{ Symbol } & \multicolumn{5}{|c|}{ Value (Euro) } \\
\hline & & $\mathbf{Z 1}$ & $\mathbf{Z 2}$ & Z3 & $\mathrm{Z4}$ & $\mathrm{Z} 5$ \\
\hline Value of animals in the zone & $c_{\mathrm{a}}$ & 0 & 0 & 0 & 0 & 0 \\
\hline Value of building relevant to the zone & $c_{\mathrm{b}}$ & 0 & 0 & 150,000 & 150,000 & 75,000 \\
\hline Value of content in the zone & $c_{\mathrm{C}}$ & 0 & 5000 & 20,000 & 15,000 & 10,000 \\
\hline $\begin{array}{l}\text { Value of internal systems, including their } \\
\text { activities, in the zone }\end{array}$ & $c_{\mathrm{S}}$ & 0 & 10,000 & 30,000 & 10,000 & 25,000 \\
\hline Total value of the object & $c_{\mathrm{t}}$ & & & 500,000 & & \\
\hline
\end{tabular}

The risk of fire or explosion of the structure (Table 3) determines an important factor in the evaluation of lightning losses. The gradation of the fire risk is based on values of specific fire load and it is defined in the standard [21]. The fire load is fixed by an expert of fire precautions or defined after consultation with the owner of the building or with his insurance-firm. The fire risk for the analyzed object has been qualified as usual (ordinary or common).

Considering the number of persons present within the zones (Table 5), a lack of special hazard was assumed within zones Z1 and Z2, and a low level of panic for zones Z3, Z4, and Z5 (Table 3).

For calculation of the risks of lightning losses using formulas from Table 1, the descriptive characteristics presented in Tables 3 and A1-A15, Tables 4-7. were replaced by corresponding values of the factors and parameters, according to the rules and formulas given in PN-EN 62305-2:2012 [21] with keeping the original symbols (included in the tables).

As the standard does not cover the railway objects, in the calculation procedure it was necessary to propose the following specific data and/or solutions:

- Calculating the equivalent collection areas of lightning flashes to and near the external lines (power, telecom, data) incoming to the object following the same or similar routes when collection areas of particular lines overlap (Table 2), and selecting the worst case characteristics (Tables A13-A15) for estimating the probabilities of damage;

- Proposing the typical mean values of losses of service to the public and of economic value due to physical damage $\mathrm{L}_{\mathrm{F}}$ and failures of internal electrical and electronic systems $\mathrm{L}_{\mathrm{O}}$, which can be regarded specific for the objects (Table 4);

- Proposing the typical mean value of loss of human life due to failures of internal electrical and electronic systems for people present in the dangerous place outside the object (zone $\mathrm{ZE}$ ) $\mathrm{L}_{\mathrm{OE}}$ (Table 4) and the time of presence of people in the place $\mathrm{t}_{\mathrm{e}}$ (Table 5), and calculating the corresponding risk of loss of human life in the outside zone ZE;

- Proposing the numbers of users served by the object, relevant to the loss of service to the public, as specific to the considered objects (Table 6);

- Proposing the economic value of the object and its content, relevant to the economic loss, as specific to the considered objects (Table 7).

In the case of railway objects, the failure of internal systems due to lightning may involve loss of human life or permanent injury of people away from the object. For example, in the case of railway and road collision due to false operation of the RTC system. This effect is not taken into account in the standards (62305-2). However, it was included in the analysis in a similar way as the case when the physical damage involves the environment and surrounding structures (including people) [21].

For this purpose, additional losses $\left(\mathrm{L}_{\mathrm{CE}}, \mathrm{L}_{\mathrm{ME}}, \mathrm{L}_{\mathrm{WE}}\right.$, and $\left.\mathrm{L}_{\mathrm{ZE}}\right)$ were taken into account as the parts of the total losses $\left(\mathrm{L}_{\mathrm{CT}}, \mathrm{L}_{\mathrm{MT}}, \mathrm{L}_{\mathrm{WT}}\right.$, and $\left.\mathrm{L}_{\mathrm{ZT}}\right)$ according to formulas (2)-(6):

$$
\mathrm{L}_{\mathrm{CT}}=\mathrm{L}_{\mathrm{C}}+\mathrm{L}_{\mathrm{CE}}
$$




$$
\begin{aligned}
\mathrm{L}_{\mathrm{MT}} & =\mathrm{L}_{\mathrm{M}}+\mathrm{L}_{\mathrm{ME}} \\
\mathrm{L}_{\mathrm{WT}} & =\mathrm{L}_{\mathrm{W}}+\mathrm{L}_{\mathrm{WE}} \\
\mathrm{L}_{\mathrm{ZT}} & =\mathrm{L}_{Z}+\mathrm{L}_{\mathrm{ZE}} \\
\mathrm{L}_{\mathrm{CE}}=\mathrm{L}_{\mathrm{ME}}=\mathrm{L}_{\mathrm{WE}} & =\mathrm{L}_{\mathrm{ZE}}=\mathrm{L}_{\mathrm{OE}} \times \mathrm{t}_{\mathrm{e}} / 8760,
\end{aligned}
$$

where:

$\mathrm{L}_{\mathrm{OE}}$ - the percentage of people injured outside the object due to failure of internal systems (Table 4);

$t_{e}$ - time of presence of people in the dangerous place outside the object (Table 5); 8760 -number of hours within a year.

The components of the risk of losses related to the presence of people in the dangerous place outside the object (zone ZE) was calculated according to the general formula (1), where the loss $\mathrm{L}_{\mathrm{XE}}\left(\mathrm{L}_{\mathrm{CE}}, \mathrm{L}_{\mathrm{ME}}, \mathrm{L}_{\mathrm{WE}}, \mathrm{L}_{\mathrm{ZE}}\right)$ was estimated according to (6) and the corresponding probability of damage $\mathrm{P}_{\mathrm{XE}}\left(\mathrm{P}_{\mathrm{CE}}, \mathrm{P}_{\mathrm{ME}}, \mathrm{P}_{\mathrm{WE}}, \mathrm{P}_{\mathrm{ZE}}\right)$ was determined as the worst case from the particular values of probability $\mathrm{P}_{\mathrm{X}}\left(\mathrm{P}_{\mathrm{C}}, \mathrm{P}_{\mathrm{M}}, \mathrm{P}_{\mathrm{W}}, \mathrm{P}_{\mathrm{Z}}\right)$, assigned to the zones of the object (Z1-Z5).

Similarly, the failure of internal systems due to lightning may involve loss of economic value away from the object. This effect, however, was not taken into account in the analysis due to difficulties in determining the typical loss of economic value outside the object.

The data presented in this section were taken as input for calculation of the risks of lightning losses in the object, in the case where no protection measures against lightning electromagnetic pulse are installed. This was taken as the base case. Then, the calculation of the risks was performed again for the case for which a set of lightning protection measures was proposed to decrease the risks to or below the tolerated values. The calculations were performed using MS Excel calculation sheets, developed specifically for the considered railway objects according to the full procedure recommended in PN-EN 62305-2:2012 [21].

\section{Results}

There are three types of losses relevant to the object: loss of human life $\left(\mathrm{L}_{1}\right)$, loss of service to the public $\left(\mathrm{L}_{2}\right)$, and loss of economic value $\left(\mathrm{L}_{4}\right)$. The loss of cultural heritage $\left(\mathrm{L}_{3}\right)$ is not applicable. Hence, the corresponding risks $R_{1}, R_{2}$, and $R_{4}$ were considered. For the decision on the necessity of protection measures the tolerated values of the risks $R_{T 1}, R_{T 2}$ and $\mathrm{R}_{\mathrm{T} 4}$ were adopted as shown in Table 8 .

Table 8. Tolerated values of lightning loss risks adopted for the analysis.

\begin{tabular}{cccc}
\hline \multirow{2}{*}{ Type of Loss } & \multicolumn{3}{c}{ Tolerable Risk } \\
\cline { 2 - 4 } & Symbol & Value & Reference \\
\hline Loss of human life & $\mathrm{R}_{\mathrm{T} 1}$ & $1.0 \times 10^{-5}$ & PN-EN 62305-2:2012 [21] \\
Loss of service to the public & $\mathrm{R}_{\mathrm{T} 2}$ & $1.0 \times 10^{-3}$ & PN-EN 62305-2:2012 [21] \\
Loss of economic value & $\mathrm{R}_{\mathrm{T} 4}$ & $1.0 \times 10^{-4}$ & Proposed \\
\hline
\end{tabular}

\subsection{Object without Protection Measures-Base Case}

Calculating the risk of lightning losses and its components requires first evaluating the numbers of dangerous events $N_{X}$, probabilities of damage $P_{X}$, and losses $L_{X}$ (Table 1). The standard procedures for evaluating these factors are complex [21] and are not included in the paper. The factors are partly calculated using numerical data and partly determined based on descriptive characteristics. For the considered base case object (without protection measures), the input data are shown in Tables 2 and A1-A11, Tables A12-A15 and Tables 3-7. The calculated/estimated numbers of dangerous events, probabilities of damage, and losses are shown in Tables 9-11, respectively. 
Table 9. Calculated numbers of dangerous events for the base case object.

\begin{tabular}{|c|c|c|c|}
\hline Lightning Flashes Related to: & Number of Dangerous Events Due to Flashes: & Symbol & Value \\
\hline \multirow{2}{*}{ the object in concern } & to the object & $\mathrm{N}_{\mathrm{D}}$ & $1.95 \times 10^{-2}$ \\
\hline & near the object & $\mathrm{N}_{\mathrm{M}}$ & $2.19 \times 10^{+0}$ \\
\hline \multirow{3}{*}{ lines incoming from direction $\mathrm{A}$} & to the line & $\mathrm{N}_{\mathrm{L}(\mathrm{A})}$ & $7.61 \times 10^{-2}$ \\
\hline & near the line & $\mathrm{N}_{\mathrm{I}(\mathrm{A})}$ & $5.75 \times 10^{+0}$ \\
\hline & to an adjacent structure connected to the line & $\mathrm{N}_{\mathrm{DJ}(\mathrm{A})}$ & $0.00 \times 10^{+0}$ \\
\hline \multirow{3}{*}{ lines incoming from direction $B$} & to the line & $\mathrm{N}_{\mathrm{L}(\mathrm{B})}$ & $5.51 \times 10^{-2}$ \\
\hline & near the line & $\mathrm{N}_{\mathrm{I}(\mathrm{B})}$ & $4.17 \times 10^{+0}$ \\
\hline & to an adjacent structure connected to the line & $\mathrm{N}_{\mathrm{DJ}(\mathrm{B})}$ & $0.00 \times 10^{+0}$ \\
\hline \multirow{3}{*}{ lines incoming from direction $\mathrm{C}$} & to the line & $\mathrm{N}_{\mathrm{L}(\mathrm{C})}$ & $2.67 \times 10^{-2}$ \\
\hline & near the line & $\mathrm{N}_{\mathrm{I}(\mathrm{C})}$ & $1.87 \times 10^{+0}$ \\
\hline & to an adjacent structure connected to the line & $\mathrm{N}_{\mathrm{DJ}(\mathrm{C})}$ & $0.00 \times 10^{+0}$ \\
\hline \multirow{3}{*}{ lines incoming from direction $\mathrm{D}$} & to the line & $\mathrm{N}_{\mathrm{L}(\mathrm{D})}$ & $5.35 \times 10^{-2}$ \\
\hline & near the line & $\mathrm{N}_{\mathrm{I}(\mathrm{D})}$ & $3.75 \times 10^{+0}$ \\
\hline & to an adjacent structure connected to the line & $\mathrm{N}_{\mathrm{DI}(\mathrm{D})}$ & $0.00 \times 10^{+0}$ \\
\hline
\end{tabular}

Table 10. Estimated probabilities of damage for the base case object.

\begin{tabular}{|c|c|c|c|c|c|c|c|}
\hline \multirow{2}{*}{ Lightning Flashes: } & \multirow{2}{*}{ Type of Damage } & \multirow{2}{*}{ Symbol } & \multicolumn{5}{|c|}{ Probability of Damage } \\
\hline & & & Z1 & $\mathbf{Z 2}$ & Z3 & $\mathbf{Z 4}$ & Z5 \\
\hline \multirow{3}{*}{$\begin{array}{l}\text { To the object in } \\
\text { concern }\end{array}$} & \multirow{3}{*}{$\begin{array}{c}\text { Injuries } \\
\text { Physical damage } \\
\text { Failure of internal } \\
\text { systems }\end{array}$} & $\mathrm{P}_{\mathrm{A}}$ & 1 & 1 & 1 & 1 & 1 \\
\hline & & $\mathrm{P}_{\mathrm{B}}$ & 1 & 1 & 1 & 1 & 1 \\
\hline & & $P_{C}$ & 1 & 0 & 1 & 1 & 1 \\
\hline Near the object & $\begin{array}{c}\text { Failure of internal } \\
\text { systems }\end{array}$ & $\mathrm{P}_{\mathrm{M}}$ & $3.7 \times 10^{-1}$ & $1.0 \times 10^{-8}$ & $8.4 \times 10^{-2}$ & $6.4 \times 10^{-3}$ & $3.2 \times 10^{-1}$ \\
\hline \multirow{3}{*}{$\begin{array}{l}\text { To the lines } \\
\text { incoming from } \\
\text { direction A }\end{array}$} & \multirow{3}{*}{$\begin{array}{c}\text { Injuries } \\
\text { Physical damage } \\
\text { Failure of internal } \\
\text { systems }\end{array}$} & $\mathrm{P}_{\mathrm{U}(\mathrm{A})}$ & 0 & 0 & 0 & 0 & $1.0 \times 10^{-2}$ \\
\hline & & $\mathrm{P}_{\mathrm{V}(\mathrm{A})}$ & 1 & 0 & 0 & 0 & 1 \\
\hline & & $\mathrm{P}_{\mathrm{W}(\mathrm{A})}$ & 1 & 0 & 0 & 0 & 1 \\
\hline $\begin{array}{l}\text { Near the lines from } \\
\text { direction A }\end{array}$ & $\begin{array}{c}\text { Failure of internal } \\
\text { systems }\end{array}$ & $P_{Z(A)}$ & 1 & 0 & 0 & 0 & 1 \\
\hline \multirow{3}{*}{$\begin{array}{l}\text { To the lines } \\
\text { incoming from } \\
\text { direction B }\end{array}$} & \multirow{3}{*}{$\begin{array}{c}\text { Injuries } \\
\text { Physical damage } \\
\text { Failure of internal } \\
\text { systems }\end{array}$} & $\mathrm{P}_{\mathrm{U}(\mathrm{B})}$ & 0 & 0 & 0 & 0 & $1.0 \times 10^{-2}$ \\
\hline & & $\mathrm{P}_{\mathrm{V}(\mathrm{B})}$ & 1 & 0 & 0 & 0 & 1 \\
\hline & & $\mathrm{P}_{\mathrm{W}(\mathrm{B})}$ & 1 & 0 & 0 & 0 & 1 \\
\hline $\begin{array}{l}\text { Near the lines from } \\
\text { direction B }\end{array}$ & $\begin{array}{c}\text { Failure of internal } \\
\text { systems }\end{array}$ & $\mathrm{P}_{\mathrm{Z}(\mathrm{B})}$ & 1 & 0 & 0 & 0 & 1 \\
\hline \multirow{3}{*}{$\begin{array}{l}\text { To the lines } \\
\text { incoming from } \\
\text { direction C }\end{array}$} & \multirow{3}{*}{$\begin{array}{c}\text { Injuries } \\
\text { Physical damage } \\
\text { Failure of internal } \\
\text { systems }\end{array}$} & $\mathrm{P}_{\mathrm{U}(\mathrm{C})}$ & 0 & 0 & $1.0 \times 10^{-2}$ & $1.0 \times 10^{-2}$ & $1.0 \times 10^{-2}$ \\
\hline & & $\mathrm{P}_{\mathrm{V}(\mathrm{C})}$ & 1 & 0 & 1 & 1 & 1 \\
\hline & & $\mathrm{P}_{\mathrm{W}(\mathrm{C})}$ & 1 & 0 & 1 & 1 & 1 \\
\hline $\begin{array}{l}\text { Near the lines from } \\
\text { direction } C\end{array}$ & $\begin{array}{c}\text { Failure of internal } \\
\text { systems }\end{array}$ & $\mathrm{P}_{\mathrm{Z}(\mathrm{C})}$ & 1 & 0 & 1 & 0.3 & 0.6 \\
\hline \multirow{3}{*}{$\begin{array}{l}\text { To the lines } \\
\text { incoming from } \\
\text { direction D }\end{array}$} & \multirow{3}{*}{$\begin{array}{c}\text { Injuries } \\
\text { Physical damage } \\
\text { Failure of internal } \\
\text { systems }\end{array}$} & $\mathrm{P}_{\mathrm{U}(\mathrm{D})}$ & 0 & 0 & $1.0 \times 10^{-2}$ & 0 & 0 \\
\hline & & $\mathrm{P}_{\mathrm{V}(\mathrm{D})}$ & 1 & 0 & 1 & 0 & 0 \\
\hline & & $\mathrm{P}_{\mathrm{W}(\mathrm{D})}$ & 1 & 0 & 1 & 0 & 0 \\
\hline $\begin{array}{l}\text { Near the lines from } \\
\text { direction D }\end{array}$ & $\begin{array}{l}\text { Failure of internal } \\
\text { systems }\end{array}$ & $P_{Z(D)}$ & 1 & 0 & 1 & 0 & 0 \\
\hline
\end{tabular}


Table 11. Calculated losses for the base case object.

\begin{tabular}{|c|c|c|c|c|c|c|c|}
\hline \multirow{2}{*}{ Type of Loss } & \multirow{2}{*}{ Type of Damage } & \multirow{2}{*}{ Symbol } & \multicolumn{5}{|c|}{ Loss } \\
\hline & & & Z1 & $\mathrm{Z2}$ & $\mathrm{Z3}$ & $\mathrm{Z4}$ & $\mathbf{Z 5}$ \\
\hline \multirow{5}{*}{$\begin{array}{c}\text { Human life of } \\
\text { injury }\end{array}$} & Injuries & $\mathrm{L}_{\mathrm{A}}$ & 0 & 0 & - & - & - \\
\hline & Injuries & $\mathrm{L}_{\mathrm{U}}$ & - & - & $4.0 \times 10^{-8}$ & $9.5 \times 10^{-9}$ & $4.8 \times 10^{-9}$ \\
\hline & Physical damage & $\mathrm{L}_{\mathrm{B}}=\mathrm{L}_{\mathrm{V}}$ & 0 & 0 & $4.0 \times 10^{-5}$ & $9.5 \times 10^{-6}$ & $4.8 \times 10^{-6}$ \\
\hline & $\begin{array}{c}\text { Failure of internal } \\
\text { systems }\end{array}$ & $\begin{array}{c}\mathrm{L}_{\mathrm{C}}=\mathrm{L}_{\mathrm{M}}= \\
\mathrm{L}_{\mathrm{W}}=\mathrm{L}_{\mathrm{Z}}\end{array}$ & 0 & 0 & $4.0 \times 10^{-4}$ & $9.5 \times 10^{-5}$ & $4.8 \times 10^{-5}$ \\
\hline & $\begin{array}{c}\text { Environmental effects } \\
\text { of failure of internal } \\
\text { systems }\end{array}$ & $\begin{array}{c}\mathrm{L}_{\mathrm{CE}}=\mathrm{L}_{\mathrm{ME}}= \\
\mathrm{L}_{\mathrm{WE}}=\mathrm{L}_{\mathrm{ZE}}\end{array}$ & \multicolumn{5}{|c|}{$3.4 \times 10^{-5}$} \\
\hline \multirow{2}{*}{$\begin{array}{l}\text { Service to the } \\
\text { public }\end{array}$} & \multirow{2}{*}{$\begin{array}{l}\text { Physical damage } \\
\text { Failure of internal } \\
\text { systems }\end{array}$} & \multirow{2}{*}{$\begin{array}{c}\mathrm{L}_{\mathrm{B}}=\mathrm{L}_{\mathrm{V}} \\
\mathrm{L}_{\mathrm{C}}=\mathrm{L}_{\mathrm{M}}= \\
\mathrm{L}_{\mathrm{W}}=\mathrm{L}_{\mathrm{Z}}\end{array}$} & 0 & 0 & $1.0 \times 10^{-5}$ & 0 & $4.0 \times 10^{-5}$ \\
\hline & & & 0 & 0 & $2.0 \times 10^{-4}$ & 0 & $8.0 \times 10^{-4}$ \\
\hline \multirow{4}{*}{ Economic value } & \multirow{4}{*}{$\begin{array}{c}\text { Injuries } \\
\text { Injuries } \\
\text { Physical damage } \\
\text { Failure of internal } \\
\text { systems }\end{array}$} & $\mathrm{L}_{\mathrm{A}}$ & 0 & 0 & - & - & - \\
\hline & & \multirow{3}{*}{$\begin{array}{c}\mathrm{L}_{\mathrm{U}} \\
\mathrm{L}_{\mathrm{B}}=\mathrm{L}_{\mathrm{V}} \\
\mathrm{L}_{\mathrm{C}}=\mathrm{L}_{\mathrm{M}}= \\
\mathrm{L}_{\mathrm{W}}=\mathrm{L}_{\mathrm{Z}}\end{array}$} & - & - & 0 & 0 & 0 \\
\hline & & & 0 & $3.0 \times 10^{-5}$ & $4.0 \times 10^{-4}$ & $3.5 \times 10^{-4}$ & $2.2 \times 10^{-4}$ \\
\hline & & & 0 & $4.0 \times 10^{-5}$ & $1.2 \times 10^{-4}$ & $4.0 \times 10^{-5}$ & $1.0 \times 10^{-4}$ \\
\hline
\end{tabular}

The calculated risks of lightning losses and their components are presented in Figures 2-4, simplified for particular components and zones.
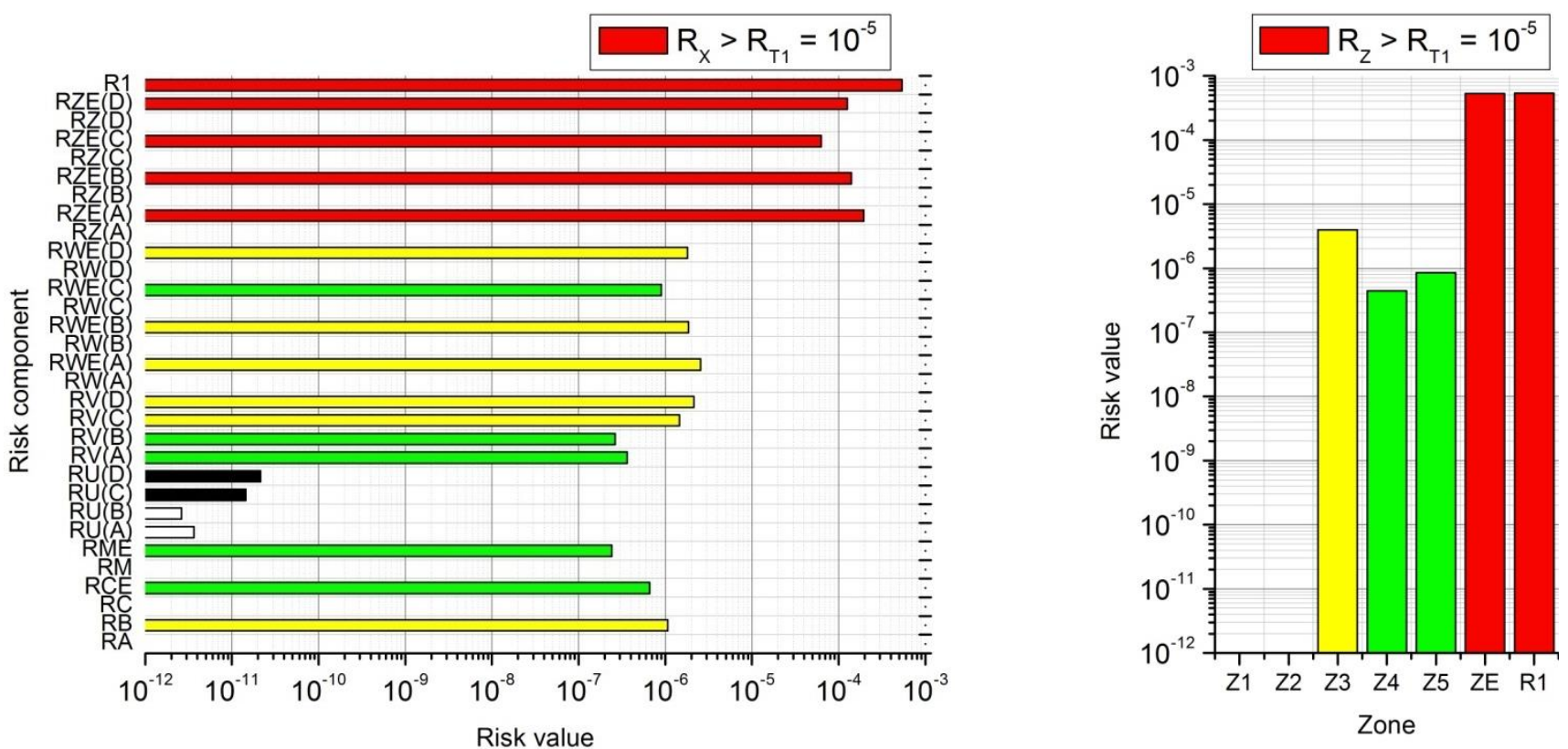

Figure 2. Calculated values of risk of loss of human life $\mathrm{R}_{1}$ and its components for the base case object (without protection measures) 

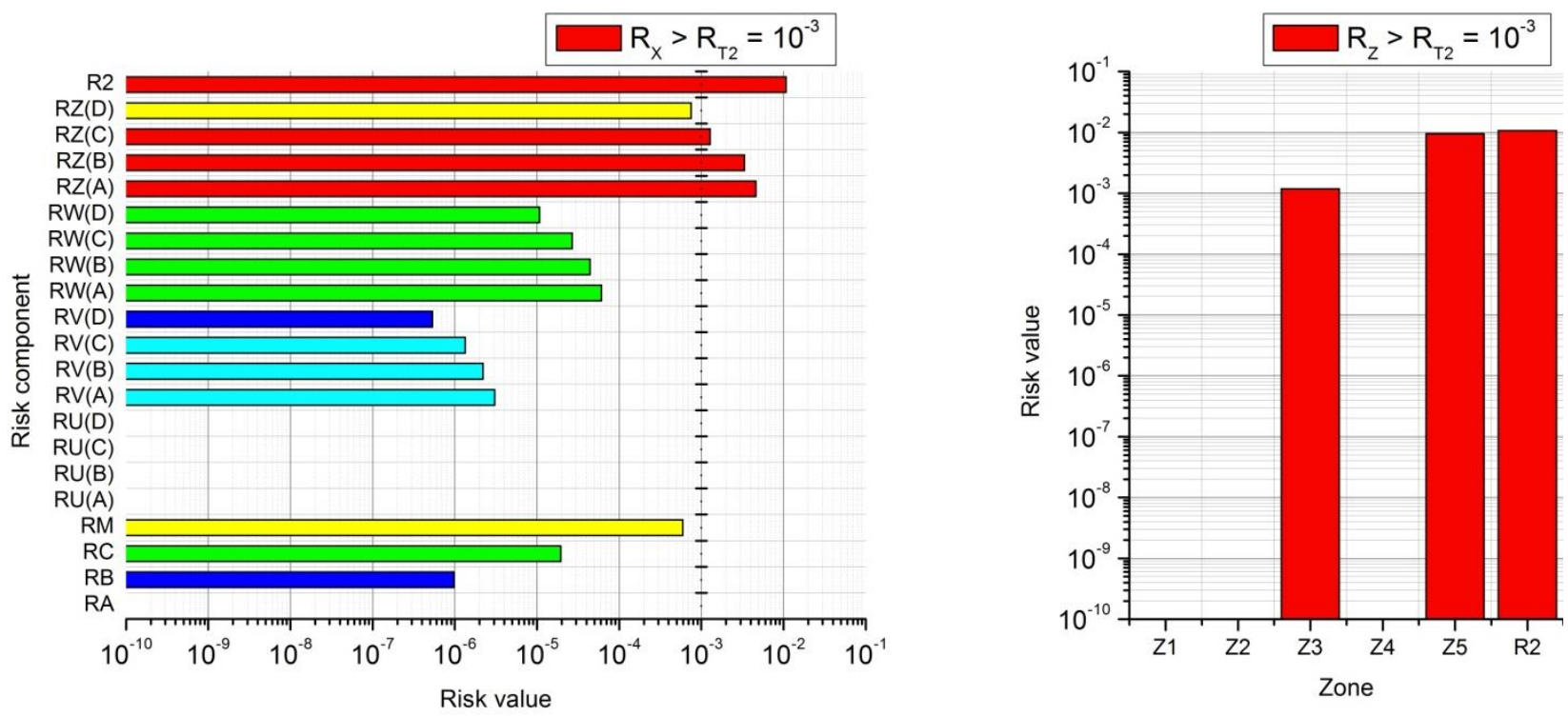

Figure 3. Calculated values of risk of loss of service to the public $R_{2}$ and its components for the base case object (without protection measures).
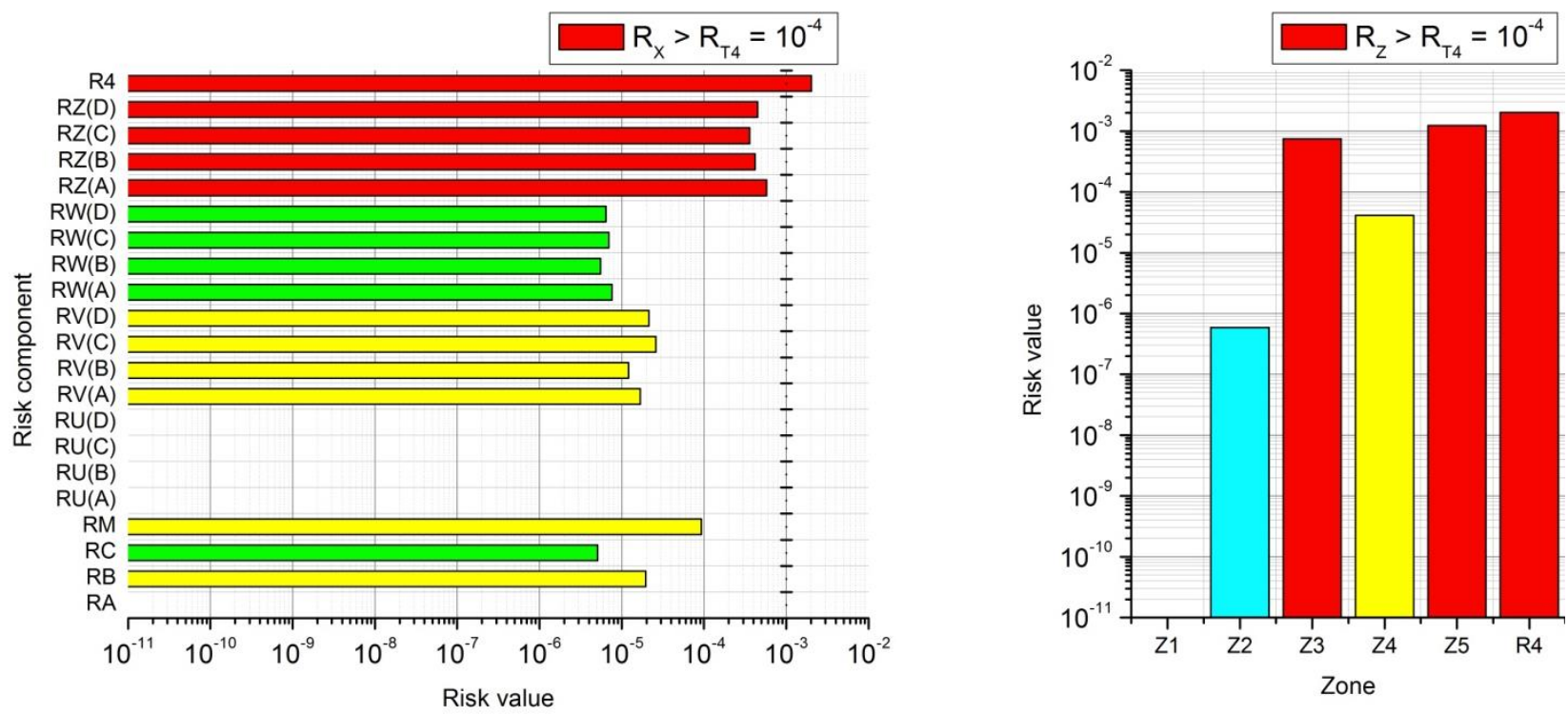

Figure 4. Calculated values of risk of loss of economic value $\mathrm{R}_{4}$ and its components for the base case object (without protection measures).

The results show that the calculated risks of loss of human life $\mathrm{R}_{1}$, loss of service to the public $R_{2}$, and loss of economic value $R_{4}$ are much higher than the tolerable values. Hence, the object requires the application of protection measures that would reduce the risks. Furthermore, the resulting values of particular risk components show which of them are the most relevant for the total values of the risks.

In the case of the risk of loss of human life, the most relevant are the risk components assigned to the environmental effects (components with subscript " $E$ ", zone ZE) of failure of internal systems, i.e., a possible loss of life or permanent injury of people, being the consequence of failure or faulty operation of RTC system. Possibly all the risk components related to these effects except for $R_{M E}$ (i.e., $R_{W E}$ and $R_{Z E}$ for all lines, and $R_{C E}$ ), may be relevant as compared with the tolerable value. Therefore, it is necessary to take provisions against failures of internal systems due to lightning flashes into and near the incoming 
lines (to reduce $R_{W E}$ and $R_{Z E}$ for all lines) as well as into the object (to reduce $R_{C E}$ ). The values of the risk components in the zones of the object (Z1-Z5) are negligible.

For the risk of loss of service to the public, the most relevant are the risk components related to the failure of internal systems due to lightning flashes near the incoming lines ( $R_{Z}$ for all lines) and near the object $\left(R_{M}\right)$. Other components can be regarded as irrelevant.

In case of the risk of economic value, similarly to the risk of loss of service to the public, the most relevant are the risk components related to the failure of internal systems due to lightning flashes near the incoming lines $\left(R_{Z}\right.$ for all lines) and near the object $\left(R_{M}\right)$. However, it is not enough to reduce these components since even if reduced to 0 , the total risk would be slightly higher than the tolerable value. Hence, in this case, it will be necessary to reduce also some less relevant components, i.e., related to the physical damage due to lightning flashes to incoming lines $\left(\mathrm{R}_{\mathrm{V}}\right.$ at least in some of the lines) and/or to the object $\left(R_{B}\right)$.

\subsection{Selection of Protection Measures and Its Characteristics-Object with Protection Measures}

Based on the analysis of the calculated risk components the protection measures have been selected. Since for each considered type of risk, the sum of the components related to injuries (D1) and physical damage (D2), i.e., $R_{A}+R_{B}+R_{U}+R_{V}$, is below the tolerable value, the external lightning protection system (LPS) is not required [21]. Hence, equipotential bonding (EB) and coordinated surge protective devices (SPDs) were the primary choices of protection measures to be applied.

Using coordinated SPDs in all the internal systems connected to incoming lines reduces the probabilities of damage and thus reduces the risk components, as indicates (1). The reduction of probability is dependent on the lightning protection level (LPL) of the coordinated SPDs. The estimated values of probabilities for the coordinated SPDs of LPL III to IV are shown in Table 12.

Table 12. Estimated probabilities of damage for the object with coordinated SPDs of LPL III to IV.

\begin{tabular}{|c|c|c|c|c|c|c|c|}
\hline \multirow{2}{*}{ Lightning Flashes: } & \multirow{2}{*}{ Type of Damage } & \multirow{2}{*}{ Symbol } & \multicolumn{5}{|c|}{ Probability of Damage } \\
\hline & & & Z1 & $\mathrm{Z2}$ & Z3 & $\mathbf{Z 4}$ & Z5 \\
\hline \multirow{3}{*}{$\begin{array}{l}\text { To the object in } \\
\text { concern }\end{array}$} & Injuries & $\mathrm{P}_{\mathrm{A}}$ & 1 & 1 & 1 & 1 & 1 \\
\hline & Physical damage & $\mathrm{P}_{\mathrm{B}}$ & 1 & 1 & $\begin{array}{l}1 \\
1\end{array}$ & $\begin{array}{l}1 \\
1\end{array}$ & 1 \\
\hline & Failure of internal systems & $\mathrm{P}_{\mathrm{C}}$ & 1 & 0 & 1 & 1 & 1 \\
\hline Near the object & Failure of internal systems & $\mathrm{P}_{\mathrm{M}}$ & $2.2 \times 10^{-2}$ & $1.0 \times 10^{-8}$ & $4.3 \times 10^{-3}$ & $3.2 \times 10^{-4}$ & $1.9 \times 10^{-2}$ \\
\hline \multirow{3}{*}{$\begin{array}{l}\text { To the lines } \\
\text { incoming from } \\
\text { direction } \mathrm{A}\end{array}$} & Injuries & $\mathrm{P}_{\mathrm{U}(\mathrm{A})}$ & 0 & 0 & 0 & 0 & $5.0 \times 10^{-4}$ \\
\hline & Physical damage & $P_{\mathrm{V}(\mathrm{A})}$ & $5.0 \times 10^{-2}$ & 0 & 0 & 0 & $5.0 \times 10^{-2}$ \\
\hline & Failure of internal systems & $\mathrm{P}_{\mathrm{W}(\mathrm{A})}$ & $5.0 \times 10^{-2}$ & 0 & 0 & 0 & $5.0 \times 10^{-2}$ \\
\hline $\begin{array}{l}\text { Near the lines from } \\
\text { direction A }\end{array}$ & Failure of internal systems & $P_{Z(A)}$ & $5.0 \times 10^{-2}$ & 0 & 0 & 0 & $5.0 \times 10^{-2}$ \\
\hline \multirow{3}{*}{$\begin{array}{l}\text { To the lines } \\
\text { incoming from } \\
\text { direction B }\end{array}$} & Injuries & $\mathrm{P}_{\mathrm{U}(\mathrm{B})}$ & 0 & 0 & 0 & 0 & $5.0 \times 10^{-4}$ \\
\hline & Physical damage & $P_{V(B)}$ & $5.0 \times 10^{-2}$ & 0 & 0 & 0 & $5.0 \times 10^{-2}$ \\
\hline & Failure of internal systems & $\mathrm{P}_{\mathrm{W}(\mathrm{B})}$ & $5.0 \times 10^{-2}$ & 0 & 0 & 0 & $5.0 \times 10^{-2}$ \\
\hline $\begin{array}{l}\text { Near the lines from } \\
\text { direction B }\end{array}$ & Failure of internal systems & $P_{Z(B)}$ & $5.0 \times 10^{-2}$ & 0 & 0 & 0 & $5.0 \times 10^{-2}$ \\
\hline \multirow{3}{*}{$\begin{array}{l}\text { To the lines } \\
\text { incoming from } \\
\text { direction } \mathrm{C}\end{array}$} & Injuries & $\mathrm{P}_{\mathrm{U}(\mathrm{C})}$ & 0 & 0 & $5.0 \times 10^{-4}$ & $5.0 \times 10^{-4}$ & $5.0 \times 10^{-4}$ \\
\hline & Physical damage & $\mathrm{P}_{\mathrm{V}(\mathrm{C})}$ & $5.0 \times 10^{-2}$ & 0 & $5.0 \times 10^{-2}$ & $5.0 \times 10^{-2}$ & $5.0 \times 10^{-2}$ \\
\hline & Failure of internal systems & $P_{W(C)}$ & $5.0 \times 10^{-2}$ & 0 & $5.0 \times 10^{-2}$ & $5.0 \times 10^{-2}$ & $5.0 \times 10^{-2}$ \\
\hline $\begin{array}{l}\text { Near the lines from } \\
\text { direction } C\end{array}$ & Failure of internal systems & $P_{Z(C)}$ & $5.0 \times 10^{-2}$ & 0 & $5.0 \times 10^{-2}$ & $1.5 \times 10^{-2}$ & $3.0 \times 10^{-2}$ \\
\hline \multirow{3}{*}{$\begin{array}{l}\text { To the lines } \\
\text { incoming from } \\
\text { direction D }\end{array}$} & Injuries & $\mathrm{P}_{\mathrm{U}(\mathrm{D})}$ & 0 & 0 & $5.0 \times 10^{-4}$ & 0 & 0 \\
\hline & Physical damage & $P_{\mathrm{V}(\mathrm{D})}$ & $5.0 \times 10^{-2}$ & 0 & $5.0 \times 10^{-2}$ & 0 & 0 \\
\hline & Failure of internal systems & $P_{W(D)}$ & $5.0 \times 10^{-2}$ & 0 & $5.0 \times 10^{-2}$ & 0 & 0 \\
\hline $\begin{array}{l}\text { Near the lines from } \\
\text { direction D }\end{array}$ & Failure of internal systems & $P_{Z(D)}$ & $5.0 \times 10^{-2}$ & 0 & $5.0 \times 10^{-2}$ & 0 & 0 \\
\hline
\end{tabular}

The calculated values of risks for the object with coordinated SPD's in the internal systems connected to incoming external lines for different LPL are presented in Table 13, 
together with the tolerable values of risks and indication of the required protection for each risk type.

Table 13. Calculated risks of losses for the object without protection and with coordinated SPDs of different LPL applied in all internal systems connected to the incoming lines.

\begin{tabular}{|c|c|c|c|}
\hline & $\begin{array}{l}R_{1}: \text { Risk of Loss of } \\
\text { Human Life }\end{array}$ & $\begin{array}{c}R_{2}: \text { Risk of Loss of Service to } \\
\text { the Public }\end{array}$ & $\begin{array}{l}\mathrm{R}_{4}: \text { Risk of Loss of } \\
\text { Economic Value }\end{array}$ \\
\hline Tolerable risk value & $1.0 \times 10^{-5}$ & $1.0 \times 10^{-3}$ & $1.0 \times 10^{-4}$ \\
\hline Without protection measures & $5.37 \times 10^{-4}$ & $1.07 \times 10^{-2}$ & $2.02 \times 10^{-3}$ \\
\hline $\begin{array}{c}\text { Coordinated SPDs of LPL } \\
\text { III-IV }\end{array}$ & $2.82 \times 10^{-5}$ & $5.61 \times 10^{-4}$ & $1.25 \times 10^{-4}$ \\
\hline Coordinated SPDs of LPL II & $1.23 \times 10^{-5}$ & $2.37 \times 10^{-4}$ & $6.48 \times 10^{-5}$ \\
\hline Coordinated SPDs of LPL I & $7.01 \times 10^{-6}$ & $1.29 \times 10^{-4}$ & $4.47 \times 10^{-5}$ \\
\hline Required protection measures & Coordinated SPDs of LPL I & $\begin{array}{l}\text { Coordinated SPDs of LPL } \\
\text { III-IV }\end{array}$ & Coordinated SPDs of LPL II \\
\hline
\end{tabular}

Coordinated SPDs of LPL III-IV allow reducing the risk of loss of service to the public below the tolerable value, however, the risks of loss of human life and loss of economic value are still too high. Reducing the risk of the loss of economic value below the tolerated value requires the coordinated SPDs of LPL II, and the risk of loss of human life- the coordinated SPDs of LPL I.

The risks of losses may also be reduced if the unshielded incoming external lines are replaced by shielded ones, as shown in Table 14 (bold font shows cases below the tolerable values).

Table 14. Calculated risks of losses for the object where unshielded incoming lines were replaced by shielded.

\begin{tabular}{|c|c|c|c|c|}
\hline & & $\begin{array}{l}\mathrm{R}_{1}: \text { Risk of Loss of } \\
\text { Human Life }\end{array}$ & $\begin{array}{l}\mathrm{R}_{2}: \text { Risk of Loss of } \\
\text { Service to the Public }\end{array}$ & $\begin{array}{l}\mathrm{R}_{4}: \text { Risk of Loss of } \\
\text { Economic Value }\end{array}$ \\
\hline \multicolumn{2}{|c|}{ Tolerable risk value } & $1.0 \times 10^{-5}$ & $1.0 \times 10^{-3}$ & $1.0 \times 10^{-4}$ \\
\hline \multicolumn{2}{|c|}{ Without protection measures } & $5.37 \times 10^{-4}$ & $1.07 \times 10^{-2}$ & $2.02 \times 10^{-3}$ \\
\hline \multirow{4}{*}{$\begin{array}{l}\text { Shielded incoming } \\
\text { external lines }\end{array}$} & $\begin{array}{l}\text { Shield not bonded to } \\
\text { the same bonding bar } \\
\text { as equipment }\end{array}$ & $9.25 \times 10^{-5}$ & $1.91 \times 10^{-3}$ & $4.92 \times 10^{-4}$ \\
\hline & $\begin{array}{l}\text { Shield bonded to the } \\
\text { same bonding bar as } \\
\text { equipment }\end{array}$ & $8.74 \times 10^{-6}$ & $7.02 \times 10^{-4}$ & $1.73 \times 10^{-4}$ \\
\hline & $\begin{array}{l}\text { Shield bonded to the } \\
\text { same bonding bar as } \\
\text { equipment + SPDs of } \\
\text { LPL III-IV }\end{array}$ & $6.45 \times 10^{-6}$ & $6.98 \times 10^{-4}$ & $1.35 \times 10^{-4}$ \\
\hline & $\begin{array}{l}\text { Shield bonded to the } \\
\text { same bonding bar as } \\
\text { equipment }+ \\
\text { coordinated SPDs of } \\
\text { LPL III-IV }\end{array}$ & $2.09 \times 10^{-6}$ & $5.94 \times 10^{-5}$ & $3.27 \times 10^{-5}$ \\
\hline
\end{tabular}

The results show that applying shielded incoming external lines allows one to reduce the risk of loss of human life and risk of loss of service to the public below the tolerable values, provided that the shield is bonded to the same bonding bar as internal equipment. Reducing the risk of loss of economic value below the tolerated level requires using in addition the coordinated surge protective devices (SPDs) of level III-IV (according to PN- 
EN 62305-4). Using the SPDs only for the purpose of equipotential bonding (according to PN-EN 62306-3) is not enough.

\section{Discussion}

Safe and reliable operation of railway traffic control systems requires the application of proper protection measures against lightning electromagnetic pulse effects, otherwise, the consequences of damage to the system may be very serious. According to the standards on lightning protection PN-EN/EN 62305, the choice of protection measures must be based on the analysis of the risk of lightning losses. The standards, however, are not addressed to the railway objects. Moreover, there are no other regulations dedicated to the railway [21,28-30].

The performed analysis of lightning risk management for a case study railway object is an attempt of adopting the recommendations of the current standard PN-EN 62305-2:2012 for the analysis of risks of lightning losses and selection of lightning protection measures in certain types of objects of railway traffic control (RTC). In the risk analysis the following issues have been solved:

- Calculating the equivalent collection areas in the case when several lines incoming to the object follow the same or similar routes and selecting the worst case characteristics for estimation of probability parameters.

- Taking into account and evaluating the amount of loss of human life due to failures of RTC systems for people present in dangerous places outside the object. The typical mean value of loss $\mathrm{L}_{\mathrm{OE}}$ was assumed as 10 times lower than for less significant parts of the hospital and the yearly time of presence of people in the dangerous places was taken as $1 / 3$ of the year.

- Proposing the mean values of loss of public service due to physical damage and failures of RTC systems. The loss factors were assumed the same as for TV and telecommunication objects.

- Proposing the mean values of economic loss due to physical damage and failures of RTC systems. The loss factors were assumed near or lower as for industrial and commercial objects.

- Proposing the number of users served by the object, relevant to the loss of service to the public.

- Estimating the economic value of the object and its content relevant to the economic loss, according to PN-EN 62305-2:2012 using the lowest reference value for typical industrial structures.

Considering the fact that not very excessive parameters and characteristics were taken for the analysis, as described in Section 2, the calculated values of risk of all the types of losses in the object without protection measures are significantly higher than the tolerable values. High values of risks are mainly related to the failures of internal systems and physical damage due to lightning flashes into or near the incoming external lines. Hence, using an external lightning protection system (LPS) on the object is not efficient in reducing these risks. An efficient solution is the application of coordinated surge protective devices (SPDs) in all the internal systems connected to incoming lines.

The coordinated SPDs of the lowest lightning protection level (LPL III-IV) are, however, sufficient only for reducing the risk of loss of service to the public. For the other risks, the coordinated SPDs of better characteristics are required: in the case of the risk of economic losses, the coordinated SPDs of LPL II, and the case of risk of loss of human life the SPDs of LPL I. Hence, to attain complete protection, the coordinated SPDs of LPL I should be installed.

Another way to reduce the risks below the tolerable values is using shielded incoming external lines instead of unshielded ones. The lines shielding allows to reduce the risk of loss of human life and risk of loss of service to the public, however, it is effective only if the shields are connected to the same bonding bar as internal equipment. In the case of the risk of loss of economic value the shielding of lines together with proper bonding of the 
shields at the entrance must be supplemented with coordinated surge protective devices of level III-IV.

Further directions of the research analysis can be related to including and valuation the amount of the loss of economic value, due to failures of RTC systems, in the case of damage to the property in dangerous places outside the object.

\section{Conclusions}

In the considered case of railway objects without protection measures, high values of risks have been obtained for all relevant types of loss, i.e., of human life, service to the public, and economic value. The calculated risks are much higher than the tolerable values.

The high risk of loss of human life is related mainly to people present outside the object, as being a consequence of failures of internal electrical and electronic systems of railway traffic control, which affect the railway automatic level crossings, remote signaling, and station equipment. The risks of loss of service to the public and loss of economic value are also basically caused by failures of internal systems. This is explained by the fact that sensitive electric and electronic internal systems must operate with a large number of various external lines (power, telecommunication, data), which are highly exposed to direct and nearby lightning flashes e.g., due to their significant length.

The practical solution that was considered to effectively reduce the risks was applying the coordinated surge protective devices (SPDs), which at the same time provide good equipotential bonding at the entry of the external lines to the object. Moreover, the values of risks of losses obtained in the object without and with protection using coordinated SPDs of different lightning protection levels (LPL) reveal that only using SPDs of sufficiently good parameters may reduce the risks below the tolerable values.

Other protection measures, whose application may be considered, are shielding of external lines and using buried lines instead of aerial. However, it should be noted that nearly all the external lines are underground and it would be very costly and inconvenient to replace the unshielded lines with shielded ones. Nevertheless, the obtained results show that the shielding of the incoming lines is effective in reducing the risk of loss of human life and risk of loss of service to the public only if the shields are bonded to the same bonding bar as internal equipment. For reducing the risk of economic value additional coordinated surge protective devices must be applied.

Taking into account that the risk calculations have been done for reliable, not very excessive input characteristics and parameters, the obtained results may be regarded as reasonable. Hence, the applied solutions and extensions, and the proposed input data characteristics may be used for managing the risks of lightning losses according to PN-EN 62305-2:2012 in the considered type of railway object. The developed calculation sheet is a useful tool for improving the risk management procedure.

Work is currently underway on a new edition of IEC 62305-2 (Ed 3), which will be based on the current general procedure of risk management. Work on the new edition of the standard aims to increase the accuracy of estimation of the risk of lightning losses, among others, by improving the procedure for assessing the density of lightning discharges using the latest data from lightning location systems. A ready-made spreadsheet will also be attached to the standard to facilitate calculations. As the more and more advanced electronic railway traffic control systems of greater sensitivity to impulse disturbances are used, it is important that the newly developed procedure and spreadsheet also included issues related to railway facilities.

Author Contributions: Conceptualization, R.M. and Z.W.; methodology, R.M. and Z.W.; software, R.M.; validation, R.M. and Z.W.; formal analysis, Z.W.; investigation, R.M. and Z.W.; resources, Z.W.; data curation, R.M. and Z.W.; writing — original draft preparation, R.M. and Z.W.; writing-review and editing, R.M. and Z.W.; visualization, R.M.; supervision, Z.W.; project administration, R.M. and Z.W.; funding acquisition, R.M. All authors have read and agreed to the published version of the manuscript. 
Funding: This research was realized in Bialystok University of Technology, Poland, and supported by the Polish Ministry of Education and Science under Rector's Project WZ/WE-IA/1/2020.

Institutional Review Board Statement: Not applicable.

Informed Consent Statement: Not applicable.

Data Availability Statement: Not applicable.

Conflicts of Interest: The authors declare no conflict of interest. The funders had no role in the design of the study; in the collection, analyses, or interpretation of data; in the writing of the manuscript, or in the decision to publish the results.

\section{List of Symbols and Abbreviations}

$A_{D}\left(m^{2}\right) \quad$ equivalent collection area for lightning flashes to an isolated object (structure),

$A_{L}\left(m^{2}\right) \quad$ equivalent collection area for lightning flashes to a line,

$\mathrm{A}_{\mathrm{I}}\left(\mathrm{m}^{2}\right) \quad$ equivalent collection area for lightning flashes near a line,

$\mathrm{A}_{\mathrm{DJ}}\left(\mathrm{m}^{2}\right)$ equivalent collection area of direct lightning flashes to an adjacent structure,

$\mathrm{A}_{\mathrm{M}}$ equivalent collection area for lightning flashes striking near a structure,

$c_{\mathrm{a}} \quad$ value of the animals, in currency,

$c_{\mathrm{b}} \quad$ value of the building, in currency,

$c_{\mathrm{C}} \quad$ value of the content of an object, in currency,

$\mathrm{C}_{\mathrm{D}} \quad$ location factor,

$\mathrm{C}_{E} \quad$ environmental factor,

$\mathrm{C}_{\mathrm{DJ}} \quad$ location factor of an adjacent structure,

$\mathrm{C}_{\mathrm{LD}} \quad$ factor depending on shielding, grounding, and isolation conditions of the line for lightning flashes to a line,

$\mathrm{C}_{\mathrm{LI}} \quad$ factor depending on shielding, grounding, and isolation conditions of the line for lightning flashes near a line,

$\mathrm{C}_{\mathrm{I}} \quad$ installation factor,

$c_{\mathrm{S}} \quad$ value of the internal systems (including their activities), in currency,

$c_{\mathrm{t}} \quad$ total value of a structure, in currency,

$\mathrm{C}_{T} \quad$ line type factor for an $\mathrm{HV} / \mathrm{LV}$ transformer on the line,

D1 injury to living beings by electric shock,

D2 physical damage,

D3 failure of internal system,

EB equipotential bonding,

EMC Electromagnetic compatibility,

GPS Global Positioning System,

$\mathrm{H}(\mathrm{m}) \quad$ height of the structure,

$h_{\mathrm{z}} \quad$ factor increasing the loss when a special hazard is present,

$\mathrm{K}_{\mathrm{S} 1} \quad$ factor relevant to the screening effectiveness of the object,

$\mathrm{K}_{\mathrm{S} 2}$ factor relevant to the screening effectiveness of shields internal to the object,

$\mathrm{K}_{\mathrm{S} 3} \quad$ factor relevant to the characteristics of internal wiring,

$\mathrm{K}_{\mathrm{S} 4}$ factor relevant to the impulse withstand voltage of internal system,

$\mathrm{L}(\mathrm{m}) \quad$ length of an object,

$\mathrm{L}_{\mathrm{L}}(\mathrm{m}) \quad$ length of a line,

$\mathrm{L}_{1} \quad$ loss of human life,

$\mathrm{L}_{2} \quad$ loss of service to the public,

$\mathrm{L}_{3} \quad$ loss of cultural heritage,

$\mathrm{L}_{4} \quad$ loss of economic value,

$\mathrm{L}_{\mathrm{A}} \quad$ loss due to injury to living beings by electric shock (flashes to the object),

$\mathrm{L}_{\mathrm{B}} \quad$ loss due to physical damage (flashes to the object),

$\mathrm{L}_{\mathrm{C}} \quad$ loss related to failure of internal systems (flashes to the object),

$\mathrm{L}_{\mathrm{M}} \quad$ loss related to failure of internal systems (flashes near the object),

$\mathrm{L}_{\mathrm{F}} \quad$ typical mean amount of loss in a structure due to physical damage,

$\mathrm{L}_{\mathrm{O}} \quad$ typical mean amount of loss in a structure due to failure of internal systems,

$\mathrm{L}_{\mathrm{T}} \quad$ typical mean amount of loss in a structure due to injury by electric shock, 


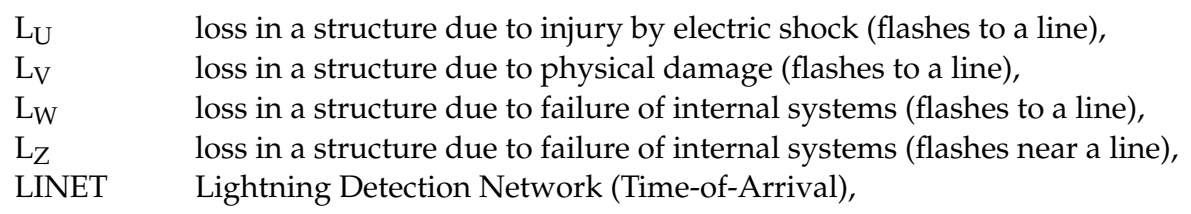
parameters relevant to the probability that the associated maximum and minimum design values will not be exceeded in naturally occurring lighting, lightning protection zone where the lightning electromagnetic environment is defined, lightning protection system (complete system used to reduce physical damage due to lightning flashes to a structure),

$\mathrm{N}_{\mathrm{D}} \quad$ number of dangerous events due to flashes to a structure (expected average annual number of dangerous events due to lightning flashes to a structure), number of dangerous events due to flashes to an adjacent structure, equipment (flashes near a line),

probability of injury to living beings by electric shock (flashes to a line), probability of physical damage to a structure (flashes to a line), probability of failure of internal systems (flashes to line), probability of failure of internal systems (flashes near a line), risk of loss of human life in a structure, risk of loss of service to the public, risk of loss of cultural heritage, risk of loss of economic value, risk component (injury to living beings-flashes to a structure), risk component (physical damage to a structure-flashes to a structure), risk component (failure of internal systems-flashes to a structure), risk components related to environmental effects of damage in an object, i.e., outside the object (failure of internal systems-flashes to a structure), factor reducing loss depending on the risk of fire, risk component (failure of internal systems-flashes near a structure), risk components related to environmental effects of damage in an object, i.e., outside the object (failure of internal systems-flashes near a structure),

$r_{\mathrm{p}} \quad$ factor reducing the loss due to provisions against fire,

$r_{\mathrm{t}} \quad$ factor reducing the loss, associated with the type of surface,

$\mathrm{R}_{\mathrm{T}} \quad$ tolerable risk-maximum value of the risk which can be tolerated for the structure to be protected,

$\mathrm{R}_{\mathrm{U}} \quad$ risk component (injury to a living being-flashes to a line),

$\mathrm{R}_{\mathrm{V}} \quad$ risk component (physical damage to the structure-flashes to a line),

$\mathrm{R}_{\mathrm{W}} \quad$ risk components (failure of internal systems-flashes to a line),

$\mathrm{R}_{\mathrm{WE}} \quad$ risk components related to environmental effects of damage in an object, i.e., outside the object (failure of internal systems-flashes to a line), 


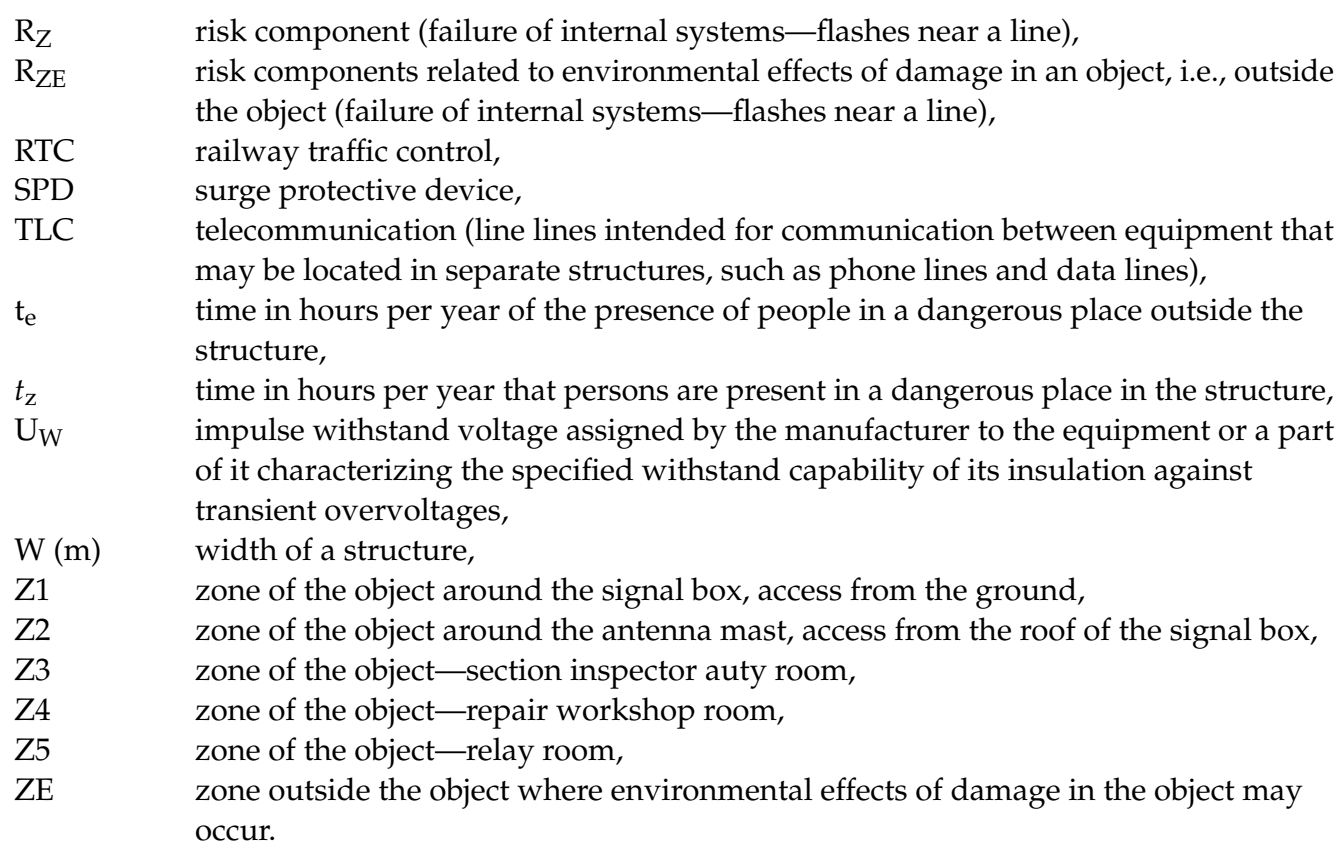

\section{Appendix A}

The characteristics of the object and incoming lines, which were used to determine the numbers of dangerous events $\mathrm{N}_{X}$ according to formula (1) and Table 1, are shown in Tables A1-A11.

Table A1. Properties of the object to be protected (signal box with aerial antenna mast on the roof).

\begin{tabular}{ccc}
\hline Parameter & Symbol & Value (Property) \\
\hline $\begin{array}{c}\text { Physical dimensions } \\
\text { Equivalent collection area of } \\
\text { direct flashes }\end{array}$ & $\mathrm{L} ; \mathrm{W} ; \mathrm{H} ; \mathrm{H}_{\max }(\mathrm{m})$ & $14 ; 10 ; 8 ; 16$ \\
Location factor & $\mathrm{A}_{\mathrm{D}}\left(\mathrm{m}^{2}\right)$ & 7238 \\
$\begin{array}{c}\text { Equivalent collection area of } \\
\text { near flashes }\end{array}$ & $\mathrm{C}_{\mathrm{D}}(-)$ & 1 (Isolated ) \\
\hline
\end{tabular}

Table A2. Properties of the feeding line 230/400 V.

\begin{tabular}{ccc}
\hline Parameter & Symbol & Value (Property) \\
\hline Length & $\mathrm{L}_{\mathrm{L}}(\mathrm{m})$ & 1000 \\
Collection area of direct & $\mathrm{A}_{\mathrm{L}}\left(\mathrm{m}^{2}\right)$ & 40,000 \\
flashes & $\mathrm{C}_{\mathrm{I}}(-)$ & 0.5 (Buried) \\
Installation factor & $\mathrm{C}_{\mathrm{T}}(-)$ & 1 (Low voltage power) \\
Line type factor & $\mathrm{C}_{\mathrm{E}}(-)$ & 0.5 (Suburban) \\
Environmental factor & $\mathrm{A}_{\mathrm{I}}\left(\mathrm{m}^{2}\right)$ & $4,000,000$ \\
Collection area of near flashes & Structure at the opposite end of the line (MV /LV station): \\
\hline ephysical dimensions & $\mathrm{L} ; \mathrm{W} ; \mathrm{H}_{;} \mathrm{H}_{\mathrm{max}}(\mathrm{m})$ & $0 ; 0 ; 0 ; 0$ \\
Collection area of direct & $\mathrm{A}_{\mathrm{DJ}}\left(\mathrm{m}^{2}\right)$ & 0 \\
flashes & $\mathrm{C}_{\mathrm{DJ}}(-)$ & 1 (Isolated) \\
Location factor & &
\end{tabular}


Table A3. Properties of the telephone line 1.

\begin{tabular}{|c|c|c|}
\hline Parameter & Symbol & Value (Property) \\
\hline \multirow{2}{*}{$\begin{array}{l}\text { Length } \\
\text { Collection area of direct } \\
\text { flashes }\end{array}$} & $\mathrm{L}_{\mathrm{L}}(\mathrm{m})$ & 1000 \\
\hline & $\mathrm{A}_{\mathrm{L}}\left(\mathrm{m}^{2}\right)$ & 40,000 \\
\hline Installation factor & $\mathrm{C}_{\mathrm{I}}(-)$ & 0.5 (Buried) \\
\hline Line type factor & $\mathrm{C}_{\mathrm{T}}(-)$ & 1 (Telecommunication) \\
\hline Environmental factor & $\mathrm{C}_{\mathrm{E}}(-)$ & 0.5 (Suburban) \\
\hline Collection area of near flashes & $\mathrm{A}_{\mathrm{I}}\left(\mathrm{m}^{2}\right)$ & $4,000,000$ \\
\hline \multicolumn{3}{|c|}{ Structure at the opposite end of the line (local exchange): } \\
\hline \multirow{3}{*}{$\begin{array}{c}\text { Physical dimensions } \\
\text { Collection area of direct } \\
\text { flashes } \\
\text { Location factor }\end{array}$} & $\mathrm{L} ; \mathrm{W} ; \mathrm{H} ; \mathrm{H}_{\max }(\mathrm{m})$ & $0 ; 0 ; 0 ; 0$ \\
\hline & $A_{D J}\left(m^{2}\right)$ & 0 \\
\hline & $\mathrm{C}_{\mathrm{DJ}}(-)$ & 1 (Isolated) \\
\hline
\end{tabular}

Table A4. Properties of the telephone line 2.

\begin{tabular}{|c|c|c|}
\hline Parameter & Symbol & Value (Property) \\
\hline Length & $\mathrm{L}_{\mathrm{L}}(\mathrm{m})$ & 1000 \\
\hline $\begin{array}{l}\text { Collection area of direct } \\
\text { flashes }\end{array}$ & $\mathrm{A}_{\mathrm{L}}\left(\mathrm{m}^{2}\right)$ & 40,000 \\
\hline Installation factor & $\mathrm{C}_{\mathrm{I}}(-)$ & 1 (Aerial) \\
\hline Line type factor & $\mathrm{C}_{\mathrm{T}}(-)$ & 1 (Telecommunication) \\
\hline Environmental factor & $\mathrm{C}_{\mathrm{E}}(-)$ & 0.5 (Suburban) \\
\hline Collection area of near flashes & $\mathrm{A}_{\mathrm{I}}\left(\mathrm{m}^{2}\right)$ & $4,000,000$ \\
\hline \multicolumn{3}{|c|}{ Structure at the opposite end of the line (local exchange): } \\
\hline Physical dimensions & $\mathrm{L} ; \mathrm{W} ; \mathrm{H} ; \mathrm{H}_{\max }(\mathrm{m})$ & $0 ; 0 ; 0 ; 0$ \\
\hline $\begin{array}{l}\text { Collection area of direct } \\
\text { flashes }\end{array}$ & $A_{D J}\left(m^{2}\right)$ & 0 \\
\hline Location factor & $\mathrm{C}_{\mathrm{DJ}}(-)$ & 1 (Isolated) \\
\hline
\end{tabular}

Table A5. Properties of the feeding line $230 / 500 \mathrm{~V}$ to the voltage box (RS).

\begin{tabular}{|c|c|c|}
\hline Parameter & Symbol & Value (Property) \\
\hline Length & $\mathrm{L}_{\mathrm{L}}(\mathrm{m})$ & 30 \\
\hline $\begin{array}{l}\text { Collection area of direct } \\
\text { flashes }\end{array}$ & $\mathrm{A}_{\mathrm{L}}\left(\mathrm{m}^{2}\right)$ & 1200 \\
\hline Installation factor & $\mathrm{C}_{\mathrm{I}}(-)$ & 0.5 (Buried) \\
\hline Line type factor & $\mathrm{C}_{\mathrm{T}}(-)$ & 1 (Low voltage power) \\
\hline Environmental factor & $\mathrm{C}_{\mathrm{E}}(-)$ & 0.5 (Suburban) \\
\hline Collection area of near flashes & $\mathrm{A}_{\mathrm{I}}\left(\mathrm{m}^{2}\right)$ & 120,000 \\
\hline \multicolumn{3}{|c|}{ Structure at the opposite end of the line (voltage box): } \\
\hline Physical dimensions & $\mathrm{L} ; \mathrm{W} ; \mathrm{H} ; \mathrm{H}_{\max }(\mathrm{m})$ & $0 ; 0 ; 0 ; 0$ \\
\hline $\begin{array}{c}\text { Collection area of direct } \\
\text { flashes }\end{array}$ & $\mathrm{A}_{\mathrm{DJ}}\left(\mathrm{m}^{2}\right)$ & 0 \\
\hline Location factor & $\mathrm{C}_{\mathrm{DJ}}(-)$ & $\begin{array}{c}0.25 \text { (Surrounded by higher } \\
\text { objects) }\end{array}$ \\
\hline
\end{tabular}


Table A6. Properties of the feeding line 230/500 V (line 1 for direction A and line 2 for direction B).

\begin{tabular}{|c|c|c|}
\hline Parameter & Symbol & Value (Property) \\
\hline \multirow{2}{*}{$\begin{array}{l}\text { Length } \\
\text { Collection area of direct } \\
\text { flashes }\end{array}$} & $\mathrm{L}_{\mathrm{L}}(\mathrm{m})$ & 1000 \\
\hline & $\mathrm{A}_{\mathrm{L}}\left(\mathrm{m}^{2}\right)$ & 40,000 \\
\hline Installation factor & $\mathrm{C}_{\mathrm{I}}(-)$ & 0.5 (Buried) \\
\hline Line type factor & $\mathrm{C}_{\mathrm{T}}(-)$ & 1 (Low voltage power) \\
\hline Environmental factor & $\mathrm{C}_{\mathrm{E}}(-)$ & 1 (Rural) \\
\hline Collection area of near flashes & $\mathrm{A}_{I}\left(\mathrm{~m}^{2}\right)$ & $4,000,000$ \\
\hline \multicolumn{3}{|c|}{ Structure at the opposite end of the line (supplied system): } \\
\hline \multirow{3}{*}{$\begin{array}{l}\text { Physical dimensions } \\
\text { Collection area of direct } \\
\text { flashes } \\
\text { Location factor }\end{array}$} & $\mathrm{L} ; \mathrm{W} ; \mathrm{H} ; \mathrm{H}_{\max }(\mathrm{m})$ & $0 ; 0 ; 0 ; 0$ \\
\hline & $A_{D J}\left(m^{2}\right)$ & 0 \\
\hline & $\mathrm{C}_{\mathrm{DJ}}(-)$ & 1 (Isolated) \\
\hline
\end{tabular}

Table A7. Properties of the control line to the automatic level crossing 1.

\begin{tabular}{|c|c|c|}
\hline Parameter & Symbol & Value (Property) \\
\hline Length & $\mathrm{L}_{\mathrm{L}}(\mathrm{m})$ & 30 \\
\hline $\begin{array}{c}\text { Collection area of direct } \\
\text { flashes }\end{array}$ & $\mathrm{A}_{\mathrm{L}}\left(\mathrm{m}^{2}\right)$ & 1200 \\
\hline Installation factor & $\mathrm{C}_{\mathrm{I}}(-)$ & 0.5 (Buried) \\
\hline Line type factor & $\mathrm{C}_{\mathrm{T}}(-)$ & 1 (Data) \\
\hline Environmental factor & $C_{E}(-)$ & 0.5 (Suburban) \\
\hline Collection area of near flashes & $\mathrm{A}_{\mathrm{I}}\left(\mathrm{m}^{2}\right)$ & 120,000 \\
\hline \multicolumn{3}{|c|}{ Structure at the opposite end of the line (crossing 1): } \\
\hline \multirow{2}{*}{$\begin{array}{l}\text { Physical dimensions } \\
\text { Collection area of direct } \\
\text { flashes }\end{array}$} & $\mathrm{L} ; \mathrm{W} ; \mathrm{H} ; \mathrm{H}_{\max }(\mathrm{m})$ & $0 ; 0 ; 0 ; 0$ \\
\hline & $\mathrm{A}_{\mathrm{DJ}}\left(\mathrm{m}^{2}\right)$ & 0 \\
\hline Location factor & $\mathrm{C}_{\mathrm{DJ}}(-)$ & $\begin{array}{c}0.25 \text { (Surrounded by higher } \\
\text { objects) }\end{array}$ \\
\hline
\end{tabular}

Table A8. Properties of the control line to the automatic level crossing 2.

\begin{tabular}{ccc}
\hline Parameter & Symbol & Value (Property) \\
\hline Length & $\mathrm{L}_{\mathrm{L}}(\mathrm{m})$ & 1420 \\
Collection area of direct & $\mathrm{A}_{\mathrm{L}}\left(\mathrm{m}^{2}\right)$ & 56,800 \\
flashes & $\mathrm{C}_{\mathrm{I}}(-)$ & 0.5 (Buried) \\
$\begin{array}{c}\text { Installation factor } \\
\text { Line type factor }\end{array}$ & $\mathrm{C}_{\mathrm{T}}(-)$ & 1 (Data) \\
Environmental factor & $\mathrm{C}_{\mathrm{E}}(-)$ & 1 (Rural) \\
Collection area of near flashes & $\mathrm{A}_{\mathrm{I}}\left(\mathrm{m}^{2}\right)$ & $5,680,000$ \\
\hline \multicolumn{2}{c}{ Structure at the opposite end of the line (crossing 2): } \\
\hline Physical dimensions & $\mathrm{L} ; \mathrm{W} ; \mathrm{H}_{;} \mathrm{H}_{\max }(\mathrm{m})$ & $0 ; 0 ; 0 ; 0$ \\
Collection area of direct & $\mathrm{A}_{\mathrm{DJ}}\left(\mathrm{m}^{2}\right)$ & 0 \\
flashes & $\mathrm{C}_{\mathrm{DJ}}(-)$ & 1 (Isolated) \\
Location factor & &
\end{tabular}


Table A9. Properties of the control line to the automatic level crossing 3.

\begin{tabular}{|c|c|c|}
\hline Parameter & Symbol & Value (Property) \\
\hline Length & $\mathrm{L}_{\mathrm{L}}(\mathrm{m})$ & 685 \\
\hline $\begin{array}{l}\text { Collection area of direct } \\
\text { flashes }\end{array}$ & $\mathrm{A}_{\mathrm{L}}\left(\mathrm{m}^{2}\right)$ & 27,400 \\
\hline Installation factor & $\mathrm{C}_{\mathrm{I}}(-)$ & 0.5 (Buried) \\
\hline Line type factor & $\mathrm{C}_{\mathrm{T}}(-)$ & 1 (Data) \\
\hline Environmental factor & $C_{E}(-)$ & 1 (Rural) \\
\hline Collection area of near flashes & $\mathrm{A}_{\mathrm{I}}\left(\mathrm{m}^{2}\right)$ & $2,740,000$ \\
\hline \multicolumn{3}{|c|}{ Structure at the opposite end of the line (crossing 3): } \\
\hline Physical dimensions & $\mathrm{L} ; \mathrm{W} ; \mathrm{H} ; \mathrm{H}_{\max }(\mathrm{m})$ & $0 ; 0 ; 0 ; 0$ \\
\hline $\begin{array}{c}\text { Collection area of direct } \\
\text { flashes }\end{array}$ & $A_{D J}\left(m^{2}\right)$ & 0 \\
\hline Location factor & $\mathrm{C}_{\mathrm{DJ}}(-)$ & 1 (Isolated) \\
\hline
\end{tabular}

Table A10. Properties of the signal line to station equipment.

\begin{tabular}{ccc}
\hline Parameter & Symbol & Value (Property) \\
\hline Length & $\mathrm{L}_{\mathrm{L}}(\mathrm{m})$ & 1000 \\
Collection area of direct & $\mathrm{A}_{\mathrm{L}}\left(\mathrm{m}^{2}\right)$ & 40,000 \\
flashes & $\mathrm{C}_{\mathrm{I}}(-)$ & 0.5 (Buried) \\
Installation factor & $\mathrm{C}_{\mathrm{T}}(-)$ & 1 (Data) \\
Line type factor & $\mathrm{C}_{\mathrm{E}}(-)$ & 1 (Rural) \\
Environmental factor & $\mathrm{A}_{\mathrm{I}}\left(\mathrm{m}^{2}\right)$ & $4,000,000$ \\
Collection area of near flashes & Structure at the opposite end of the line (station equipment): \\
\hline Physical dimensions & $\mathrm{L} ; \mathrm{W} ; \mathrm{H}_{\mathrm{H}} \mathrm{H}_{\max }(\mathrm{m})$ & $0 ; 0 ; 0 ; 0$ \\
Collection area of direct & $\mathrm{A}_{\mathrm{DJ}}\left(\mathrm{m}^{2}\right)$ & 0 \\
flashes & $\mathrm{C}_{\mathrm{DJ}}(-)$ & 1 (Isolated) \\
\hline Location factor & &
\end{tabular}

Table A11. Properties of the signal lines for remote signaling: line 1 (direction A) line 2 (direction B).

\begin{tabular}{ccc}
\hline Parameter & Symbol & Value (Property) \\
\hline Length & $\mathrm{L}_{\mathrm{L}}(\mathrm{m})$ & 1000 \\
Collection area of direct & $\mathrm{A}_{\mathrm{L}}\left(\mathrm{m}^{2}\right)$ & 40,000 \\
flashes & $\mathrm{C}_{\mathrm{I}}(-)$ & 0.5 (Buried) \\
Installation factor & $\mathrm{C}_{\mathrm{T}}(-)$ & 1 (Data) \\
Line type factor & $\mathrm{C}_{\mathrm{E}}(-)$ & 1 (Rural) \\
Environmental factor & $\mathrm{A}_{\mathrm{I}}\left(\mathrm{m}^{2}\right)$ & $4,000,000$ \\
Collection area of near flashes & Structure at the opposite end of the line (signaling equipment): \\
\hline Physical dimensions & $\mathrm{L} ; \mathrm{W} ; \mathrm{H}_{;} \mathrm{H}_{\max }(\mathrm{m})$ & $0 ; 0 ; 0 ; 0$ \\
Collection area of direct & $\mathrm{A}_{\mathrm{DJ}}\left(\mathrm{m}^{2}\right)$ & 0 \\
flashes & $\mathrm{C}_{\mathrm{DJ}}(-)$ & 1 (Isolated) \\
Location factor & &
\end{tabular}




\section{Appendix B}

The specific characteristics of the object (signal box), incoming external lines, internal electrical and electronic systems installed in the object, and applied protection measures against electric shock, lightning, and overvoltage, that are needed to determine the values of probabilities of damage $\mathrm{P}_{\mathrm{X}}$ (formulas: (1) and in Table 1), are presented in Tables A12-A15.

Table A12. Characteristics of the object (signal box with antenna mast) affecting the probabilities of damage.

\begin{tabular}{|c|c|c|c|c|c|c|}
\hline \multirow{2}{*}{ Property } & \multirow{2}{*}{ Parameter } & \multicolumn{5}{|c|}{ Characteristics } \\
\hline & & Z1 & $\mathrm{Z2}$ & Z3 & $\mathrm{Z4}$ & Z5 \\
\hline $\begin{array}{l}\text { Lightning protection system } \\
\text { (LPS) }\end{array}$ & $P_{B}$ & No protection & No protection & No protection & No protection & No protection \\
\hline $\begin{array}{c}\text { Protection against electric } \\
\text { shock due to a direct } \\
\text { lightning flash }\end{array}$ & $\mathrm{P}_{\mathrm{TA}}$ & No protection & No protection & No protection & No protection & No protection \\
\hline $\begin{array}{l}\text { Screening effectiveness of } \\
\text { the structure at the boundary } \\
\text { LPZ } 0 / 1\end{array}$ & $\mathrm{~K}_{\mathrm{S} 1}$ & No shielding & No shielding & No shielding & No shielding & No shielding \\
\hline $\begin{array}{c}\text { Screening effectiveness of } \\
\text { internal shields, i.e. within } \\
\text { LPZ } 1\end{array}$ & $\mathrm{~K}_{\mathrm{S} 2}$ & No shielding & No shielding & No shielding & No shielding & No shielding \\
\hline
\end{tabular}

Table A13. Characteristics of the incoming lines to which the internal systems are connected.

\begin{tabular}{|c|c|c|c|c|c|}
\hline \multirow{3}{*}{ Internal System } & \multirow{3}{*}{$\begin{array}{c}\text { Zones where } \\
\text { Internal System } \\
\text { Extends }\end{array}$} & \multicolumn{2}{|c|}{$\mathrm{C}_{\mathrm{LD}}, \mathrm{C}_{\mathrm{LI}}, \mathrm{P}_{\mathrm{LD}}$} & $\mathbf{P}_{\mathrm{LD}}$ & $\mathbf{P}_{\text {LI }}$ \\
\hline & & \multicolumn{2}{|c|}{$\begin{array}{l}\text { Shielding, Grounding, and Isolation } \\
\text { Conditions of the Incoming Line }\end{array}$} & \multirow{2}{*}{$\begin{array}{c}\text { Resistance } R_{S} \text { of } \\
\text { the Shield } \\
(\Omega / \mathrm{km})\end{array}$} & \multirow{2}{*}{ Line Type } \\
\hline & & Line Type & $\begin{array}{l}\text { Connection at } \\
\text { Entrance }\end{array}$ & & \\
\hline Antenna & $\mathrm{Z} 2, \mathrm{Z3}$ & Aerial, shielded & $\begin{array}{l}\text { No connection } \\
\text { (internal line) }\end{array}$ & $(5 ; 20\rangle$ & Telecom \\
\hline Power $230 / 400 \mathrm{~V}$ & $\mathrm{Z1}, \mathrm{Z3}, \mathrm{Z4}, \mathrm{Z5}$ & Buried, unshielded & & & Power \\
\hline Power $230 / 500 \mathrm{~V}$ & $\mathrm{Z1}, \mathrm{Z} 5$ & Buried, unshielded & & & Power \\
\hline Telecommunication 1 & $\mathrm{Z1}, \mathrm{Z3}$ & Buried, unshielded & & & Telecom \\
\hline Telecommunication 2 & $\mathrm{Z1}, \mathrm{Z3}$ & Aerial, unshielded & & & Telecom \\
\hline Control of crossing 1 & $\mathrm{Z1}, \mathrm{Z} 5$ & Buried, unshielded & & & Telecom \\
\hline Control of crossing 2 & $\mathrm{Z1}, \mathrm{Z5}$ & Buried, unshielded & & & Telecom \\
\hline Control of crossing 3 & $\mathrm{Z1}, \mathrm{Z5}$ & Buried, unshielded & & & Telecom \\
\hline Station equipment & $\mathrm{Z1}, \mathrm{Z5}$ & Buried, unshielded & & & Telecom \\
\hline Signaling 1 & $\mathrm{Z1}, \mathrm{Z5}$ & Buried, unshielded & & & Telecom \\
\hline Signaling 2 & $\mathrm{Z1}, \mathrm{Z} 5$ & Buried, unshielded & & & Telecom \\
\hline
\end{tabular}


Table A14. Characteristics of the internal systems within the object.

\begin{tabular}{|c|c|c|c|c|c|}
\hline \multicolumn{6}{|c|}{ a. Type of internal wiring. } \\
\hline \multirow{3}{*}{ Internal System } & \multicolumn{5}{|c|}{$\mathrm{K}_{\mathrm{S} 3}$} \\
\hline & \multicolumn{5}{|c|}{ Type of Internal Wiring of the System } \\
\hline & $\mathbf{Z 1}$ & $\mathbf{Z 2}$ & $\mathbf{Z 3}$ & Z4 & $\mathbf{Z 5}$ \\
\hline Antenna & - & Shielded & Shielded & - & - \\
\hline Power $230 / 400 \mathrm{~V}$ & $\begin{array}{l}\text { Unshielded, route } \\
\text { avoiding large loops }\end{array}$ & - & $\begin{array}{c}\text { Unshielded, route } \\
\text { avoiding large } \\
\text { loops }\end{array}$ & $\begin{array}{l}\text { Unshielded, route } \\
\text { avoiding large } \\
\text { loops }\end{array}$ & $\begin{array}{c}\text { Unshielded, route } \\
\text { avoiding large } \\
\text { loops }\end{array}$ \\
\hline Power $230 / 500 \mathrm{~V}$ & $\begin{array}{l}\text { Unshielded, route } \\
\text { avoiding large loops }\end{array}$ & - & 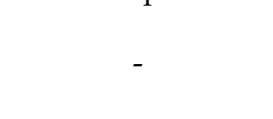 & -1 & $\begin{array}{c}\text { Unshielded, route } \\
\text { avoiding large } \\
\text { loops }\end{array}$ \\
\hline Telecom. 1 & $\begin{array}{l}\text { Unshielded, route } \\
\text { avoiding large loops }\end{array}$ & - & $\begin{array}{l}\text { Unshielded, route } \\
\text { avoiding large } \\
\text { loops }\end{array}$ & - & 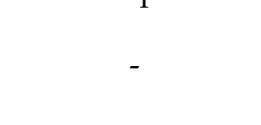 \\
\hline Telecom. 2 & $\begin{array}{l}\text { Unshielded, route } \\
\text { avoiding large loops }\end{array}$ & - & $\begin{array}{c}\text { Unshielded, route } \\
\text { avoiding large } \\
\text { loops }\end{array}$ & - & - \\
\hline Control of crossing 1 & $\begin{array}{l}\text { Unshielded, route } \\
\text { avoiding large loops }\end{array}$ & - & $x_{0}$ & - & $\begin{array}{c}\text { Unshielded, route } \\
\text { avoiding large } \\
\text { loops }\end{array}$ \\
\hline Control of crossing 2 & $\begin{array}{l}\text { Unshielded, route } \\
\text { avoiding large loops }\end{array}$ & - & - & - & $\begin{array}{c}\text { Unshielded, route } \\
\text { avoiding large } \\
\text { loops }\end{array}$ \\
\hline Control of crossing 3 & $\begin{array}{c}\text { Unshielded, route } \\
\text { avoiding large loops }\end{array}$ & - & - & - & $\begin{array}{c}\text { Unshielded, route } \\
\text { avoiding large } \\
\text { loops }\end{array}$ \\
\hline Station equipment & $\begin{array}{l}\text { Unshielded, route } \\
\text { avoiding large loops }\end{array}$ & - & - & - & $\begin{array}{c}\text { Unshielded, route } \\
\text { avoiding large } \\
\text { loops }\end{array}$ \\
\hline Signaling 1 & $\begin{array}{l}\text { Unshielded, route } \\
\text { avoiding large loops }\end{array}$ & - & - & - & $\begin{array}{c}\text { Unshielded, route } \\
\text { avoiding large } \\
\text { loops }\end{array}$ \\
\hline Signaling 2 & $\begin{array}{c}\text { Unshielded, route } \\
\text { avoiding large loops }\end{array}$ & - & - & - & $\begin{array}{c}\text { Unshielded, route } \\
\text { avoiding large } \\
\text { loops }\end{array}$ \\
\hline \multicolumn{6}{|c|}{ b. Impulse withstand voltage. } \\
\hline \multirow{3}{*}{ Internal System } & \multicolumn{5}{|c|}{$\mathrm{K}_{\mathrm{S} 4}, \mathbf{P}_{\mathrm{LD}}, \mathbf{P}_{\mathrm{LI}}$} \\
\hline & \multicolumn{5}{|c|}{ Lowest Impulse Withstand Voltage $\mathrm{U}_{\mathrm{W}}(\mathrm{kV})$} \\
\hline & Z1 & $\mathbf{Z 2}$ & Z3 & $\mathbf{Z 4}$ & $\mathbf{Z 5}$ \\
\hline Antenna & - & 1.0 & 1.0 & - & - \\
\hline Power $230 / 400 \mathrm{~V}$ & 2.5 & - & 2.5 & 2.5 & 1.5 \\
\hline Power $230 / 500 \mathrm{~V}$ & 1.0 & - & - & - & 1.0 \\
\hline Telecommunication 1 & 1.0 & - & 1.0 & - & - \\
\hline Telecommunication 2 & 1.0 & - & 1.0 & - & - \\
\hline Control of crossing 1 & 1.0 & - & - & - & 1.0 \\
\hline Control of crossing 2 & 1.0 & - & - & - & 1.0 \\
\hline Control of crossing 3 & 1.0 & - & - & - & 1.0 \\
\hline Station equipment & 1.0 & - & - & - & 1.0 \\
\hline Signaling 1 & 1.0 & - & - & - & 1.0 \\
\hline Signaling 2 & 1.0 & - & - & - & 1.0 \\
\hline
\end{tabular}


Table A15. Characteristics of the protection measures in the internal systems within the object.

\begin{tabular}{|c|c|c|c|c|c|}
\hline \multicolumn{6}{|c|}{ a. Protection against electric shock. } \\
\hline \multirow[b]{2}{*}{ Internal System } & \multicolumn{5}{|c|}{$\mathbf{P}_{\mathrm{TU}}$} \\
\hline & \multicolumn{5}{|c|}{ Protection against Electric Shock Due to the Flash to the Incoming Line } \\
\hline Antenna & - & $\begin{array}{l}\text { Electrical insulation, } \\
\text { physical restrictions }\end{array}$ & $\begin{array}{l}\text { Electrical } \\
\text { insulation }\end{array}$ & - & - \\
\hline Power $230 / 400 \mathrm{~V}$ & $\begin{array}{l}\text { Electrical insulation, } \\
\text { physical restrictions }\end{array}$ & - & $\begin{array}{l}\text { Electrical } \\
\text { insulation }\end{array}$ & $\begin{array}{l}\text { Electrical } \\
\text { insulation }\end{array}$ & $\begin{array}{l}\text { Electrical } \\
\text { insulation }\end{array}$ \\
\hline Power $230 / 500 \mathrm{~V}$ & $\begin{array}{l}\text { Electrical insulation, } \\
\text { physical restrictions }\end{array}$ & - & - & - & $\begin{array}{l}\text { Electrical } \\
\text { insulation }\end{array}$ \\
\hline Telecom. 1 & $\begin{array}{l}\text { Electrical insulation, } \\
\text { physical restrictions }\end{array}$ & - & $\begin{array}{l}\text { Electrical } \\
\text { insulation }\end{array}$ & - & - \\
\hline Telecom. 2 & $\begin{array}{l}\text { Electrical insulation, } \\
\text { physical restrictions }\end{array}$ & - & $\begin{array}{l}\text { Electrical } \\
\text { insulation }\end{array}$ & - & - \\
\hline Control of crossing 3 & $\begin{array}{l}\text { Electrical insulation, } \\
\text { physical restrictions }\end{array}$ & - & - & - & $\begin{array}{l}\text { Electrical } \\
\text { insulation }\end{array}$ \\
\hline Station equipment & $\begin{array}{l}\text { Electrical insulation, } \\
\text { physical restrictions }\end{array}$ & - & - & - & $\begin{array}{l}\text { Electrical } \\
\text { insulation }\end{array}$ \\
\hline Signaling 1 & $\begin{array}{l}\text { Electrical insulation, } \\
\text { physical restrictions }\end{array}$ & - & - & - & $\begin{array}{l}\text { Electrical } \\
\text { insulation }\end{array}$ \\
\hline Signaling 2 & $\begin{array}{l}\text { Electrical insulation, } \\
\text { physical restrictions }\end{array}$ & - & - & - & $\begin{array}{l}\text { Electrical } \\
\text { insulation }\end{array}$ \\
\hline \multicolumn{6}{|c|}{ b. Coordinated surge protective devices. } \\
\hline \multirow[b]{2}{*}{ Internal System } & \multicolumn{5}{|c|}{$\mathbf{P}_{\text {SPD }}$} \\
\hline & \multicolumn{5}{|c|}{ Coordinated Surge Protective Devices (SPD's) in the Internal System } \\
\hline Power $230 / 500 \mathrm{~V}$ & No coordinated SPDs & - & - & - & $\begin{array}{l}\text { No coordinated } \\
\text { SPDs }\end{array}$ \\
\hline Telecom. 1 & No coordinated SPDs & - & $\begin{array}{c}\text { No } \\
\text { coordinated } \\
\text { SPDs }\end{array}$ & - & 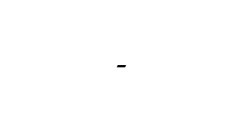 \\
\hline Telecom. 2 & No coordinated SPDs & - & $\begin{array}{c}\text { No } \\
\text { coordinated } \\
\text { SPDs }\end{array}$ & - & - \\
\hline Control of crossing 1 & No coordinated SPDs & - & - & - & $\begin{array}{l}\text { No coordinated } \\
\text { SPDs }\end{array}$ \\
\hline Control of crossing 2 & No coordinated SPDs & - & - & - & $\begin{array}{l}\text { No coordinated } \\
\text { SPDs }\end{array}$ \\
\hline Control of crossing 3 & No coordinated SPDs & - & - & - & $\begin{array}{c}\text { No coordinated } \\
\text { SPDs }\end{array}$ \\
\hline Station equipment & No coordinated SPDs & - & - & - & $\begin{array}{l}\text { No coordinated } \\
\text { SPDs }\end{array}$ \\
\hline Signaling 1 & No coordinated SPDs & - & - & - & $\begin{array}{l}\text { No coordinated } \\
\text { SPDs }\end{array}$ \\
\hline Signaling 2 & No coordinated SPDs & - & - & - & $\begin{array}{l}\text { No coordinated } \\
\text { SPDs }\end{array}$ \\
\hline
\end{tabular}


Table A15. Cont

\begin{tabular}{|c|c|c|c|c|c|}
\hline \multicolumn{6}{|c|}{ c. Equipotential bonding. } \\
\hline \multirow{3}{*}{ Internal System } & \multicolumn{5}{|c|}{$\mathbf{P}_{\text {EB }}$} \\
\hline & \multicolumn{5}{|c|}{ Equipotential Bonding Provided by SPD at the Entry of the Incoming Line } \\
\hline & Z1 & $\mathrm{Z2}$ & Z3 & Z4 & Z5 \\
\hline Antenna & - & No SPD & No SPD & - & - \\
\hline Power $230 / 400 \mathrm{~V}$ & No SPD & - & No SPD & No SPD & No SPD \\
\hline Power $230 / 500 \mathrm{~V}$ & No SPD & - & - & - & No SPD \\
\hline Telecom. 1 & No SPD & - & No SPD & - & No SPD \\
\hline Telecom. 2 & No SPD & - & No SPD & - & No SPD \\
\hline Control of crossing 1 & No SPD & - & - & - & No SPD \\
\hline Control of crossing 2 & No SPD & - & - & - & No SPD \\
\hline Control of crossing 3 & No SPD & - & - & - & No SPD \\
\hline Station equipment & No SPD & - & - & - & No SPD \\
\hline Signaling 1 & No SPD & - & - & - & No SPD \\
\hline Signaling 2 & No SPD & - & & & No SPD \\
\hline
\end{tabular}

\section{References}

1. Unpublished proprietary material of PKP Polish Railway Lines JSC, Railway Lines Establishment in Rzeszów®, made available for the purpose of this work.

2. Jakubowski, J.L. Podstawy Teorii Przepięć w Układach Energoelektrycznych (Fundamentals of Overvoltage Theory in Power Systems); PWN: Warszawa, Poland, 1968.

3. Linie I Stacje Elektroenergetyczne W Środowisku Człowieka (Power Lines and Stations in the Human Environment), Informator (Register); PSE-Operator: Warszawa, Poland, 2008.

4. Krehbiel, P.R.; Brook, M.; McCrory, R.A. An Analysis of the Charge Structure of Lightning Discharges to Ground. J. Geophys. Res. 1979, 84, 2432-2456. [CrossRef]

5. Rakov, V.A.; Uman, M. Lightning. Physics and Effects; Cambridge University: Cambridge, UK, 2005.

6. Wróbel, Z. Surge threats appear in railway devices feeding lines. In Proceedings of the 34th International Conference on Lightning Protection, ICLP2018, Rzeszow, Poland, 2-7 September 2018.

7. Wróbel, Z. The Group and Individual Connection to the Rail System Modelling in a Lightning Discharge Analysis. In Proceedings of the 11th Scientific Conference on Selected Issues of Electrical Engineering and Electronics (WZEE), Rzeszow, Poland, 27-30 September 2013.

8. Wróbel, Z. Simulation Possibility of Performance of Avalanche Diode Using a Combination Wave Generator. In Proceedings of the 20th IEEE International Symposium on Industrial Electronics (ISIE), Gdansk, Poland, 27-30 June 2011.

9. Laskowski, M.; Malesa, R.; Wróbel, Z. Określenie Istniejących Poziomów Zakłóceń Elektromagnetycznych W Ruchomych I Stacjonarnych Obiektach Kolejowych (Determination of the Existing Levels of Electromagnetic Interference in Mobile and Stationary Railway Facilities); Praca CNTK (Zakład Telekomunikacji): Warszawa, Poland, 1997.

10. Rakov, V.A. Transient response of a tall object to lightning. IEEE Trans. Electromagn. Compat. 2001, 43, 654-661. [CrossRef]

11. Heidler, F. Traveling Current source model for LEMP calculation. In Proceedings of the 6th Symposium EMC, Zurich, Switzerland, 5-7 March 1985; pp. 157-162.

12. Nucci, C.A. Lightning Induced Overvoltages on Overhead Power Lines. Part I: Return Stroke Current Models with Specified Channel-Base Current for The Evaluation of Return Stroke Electromagnetic Fields; CIGRE Electra: Paris, France, 1995; No 161.

13. Nucci, C.A. Lightning Induced Overvoltages on Overhead Power Lines. Part II: Coupling Models for the Evaluation of the Induced Voltages; CIGRE Electra: Paris, France, 1995; No 162.

14. Nucci, C.A.; Borghetti, A.; Piantini, A.; Janiszewski, J.M. Lightning Induced Voltages on Distribution Overhead Lines: Comparison Between Experimental Results from a Reduced-Scale Models and Most Reduced Approaches. In Proceedings of the 24th International Conference on Lightning Protection ICLP'98, Birmingham, UK, 14-18 September 1998; pp. 314-320.

15. Loboda, M.; Szewczyk, M.; Flisowski, Z. Lightning risk numerical calculation programme based on new version of IEC $62305-2$. In Proceedings of the 26th International Conference on Lightning Protection (ICLP 2002), Cracow, Poland, 2-6 September 2002; Volume II, 10b.4, pp. 842-847.

16. Markowska, R.; Sowa, A.W. Ochrona Odgromowa Obiektów Radiokomunikacyjnych (Lightning Protection of Radio Communication Objects); Oficyna Wydawnicza Politechniki Białostockiej: Białystok, Poland, 2013.

17. Surtees, A.J.; Gillespie, A.; Kern, A.; Rousseau, A. Development of a risk assessment calculator based on a simplified form of the IEC 62305-2 standard on lighting protection. In Proceedings of the 27th International Conference on Lightning Protection (ICLP 2004), Avignon, France, 13-16 September 2004.

18. Sowa, A.; Flisowski, Z. Determination of voltages induced in communication and control lines by lightning. In Proceedings of the 16th International Conference on Lightning Protection (ICLP), SZEGED (Budapest), Hungary; 1981. Paper 2.07. 
19. IEC Standards Publication. PN-EN 62305-1:2011/EN 62305-1:2011/IEC 62305-1:2010, Protection against Lightning-Part 1: General Principles; IEC Standards Publication: Geneva, Switzerland, 2010.

20. IEC Standards Publication. PN-EN 62305-2:2008/EN 62305-2:2006, Protection against Lightning-Part 2: Risk Management; IEC Standards Publication: Geneva, Switzerland, 2006.

21. IEC Standards Publication. PN-EN 62305-2:2012/EN 62305-2:2012/IEC 62305-2:2010, Protection against lightning-Part 2: Risk management; IEC Standards Publication: Geneva, Switzerland, 2010.

22. IEC Standards Publication. PN-EN 62305-3:2011/EN 62305-3:2011/IEC 62305-3:2010, Protection against Lightning-Part 3: Physical Damage to Structures and Life Hazard; IEC Standards Publication: Geneva, Switzerland, 2010.

23. IEC Standards Publication. PN-EN 62305-4:2011/EN 62305-4:2011/IEC 62305-4:2010, Protection against Lightning. Part 4: Electrical and Electronic Systems within Structures; IEC Standards Publication: Geneva, Switzerland, 2010.

24. ITU-T Recommendation, K.39. (10/1996), Series K: Risk Assessment of Damages to Telecommunication Sites Due to Lightning Discharge; International Telecommunication Union: Geneva, Switzerland, 1996.

25. Rousseau, A.; Kern, A. How to deal with environmental risk in IEC 62305-2. In Proceedings of the 32nd International Conference on Lightning Protection (ICLP), Shanghai, China, 11-18 October 2014. Paper 149.

26. Surtes, A.J.; Gilespie, A.; Kern, A.; Rousseau, A. The Risk Assessment Calculator as a Simple Tool for the Application of the Standard IEC 62305-2. In Proceedings of the 8th International Symposium on Lightning Protection, Sao Paulo, Brazil, 21-25 November 2005.

27. Wincencik, K. Ochrona Odgromowa Wedtug Nowych Polskich Norm (Lightning Protection according to New Polish Standards); Wiedza i praktyka: Warszawa, Poland, 2018.

28. Wróbel, Z.; Jagiełło, A.S. The Risk of Lightning Losses in a Structure Equipped with RTC Devices According to the Standard EN 62305-2.2008. Energies 2021, 14, 1704. [CrossRef]

29. Wróbel, Z. The Horn Gap Arresters Modelling in a Lightning Discharge Analysis. In Proceedings of the 13th Scientific Conference on Selected Issues of Electrical Engineering and Electronics (WZEE), Rzeszow, Poland, 4-8 May 2016.

30. Wymagania Techniczne dla Zapewnienia Ochrony Przed Przepięciamii od Wyładowań Atmosferycznych Urządzeń Sterowania Ruchem kolejowym, Łaczności i DSAT (Technical Requirements for Protection Against Overvoltage and Lightning Discharges of Railway Traffic Control, Communication and DSAT Devices). Report. Ie-120; PKP Polskie Linie Kolejowe: Warszawa, Poland, 2017. 